\title{
REPORT TO THE CONGRESS
}

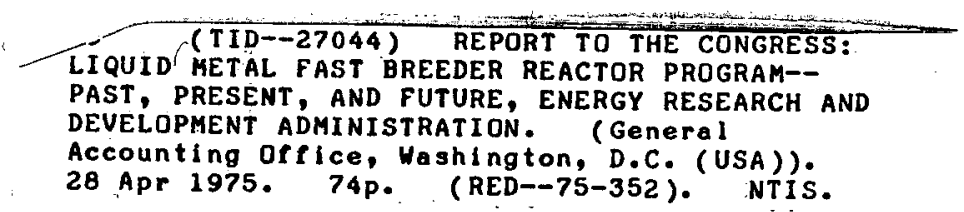

The Liquid Metal

Fast Breeder Reactor Programighang
Past, Present, And Future

Energy Research and Develop "ent Administration

\section{BY THE COMPTROLLER GENERAL OF TIE UNITED STATES}

RED -75.352

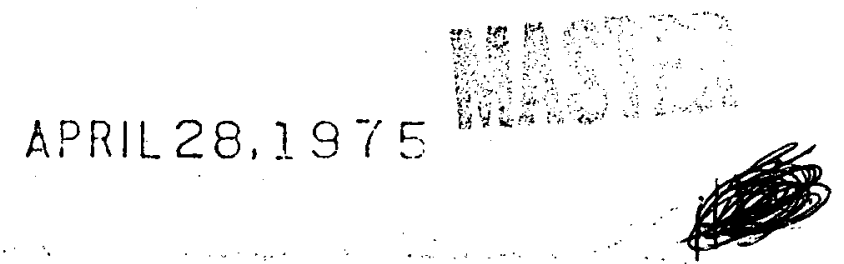




\section{DISCLAIMER}

This report was prepared as an account of work sponsored by an agency of the United States Government. Neither the United States Government nor any agency Thereof, nor any of their employees, makes any warranty, express or implied, or assumes any legal liability or responsibility for the accuracy, completeness, or usefulness of any information, apparatus, product, or process disclosed, or represents that its use would not infringe privately owned rights. Reference herein to any specific commercial product, process, or service by trade name, trademark, manufacturer, or otherwise does not necessarily constitute or imply its endorsement, recommendation, or favoring by the United States Government or any agency thereof. The views and opinions of authors expressed herein do not necessarily state or reflect those of the United States Government or any agency thereof. 


\section{DISCLAIMER}

Portions of this document may be illegible in electronic image products. Images are produced from the best available original document. 
To the President of the senate and the Speaker of the House of Representatives

This is our report on the liguid metal fast breeder reactor proaram--past, present, and future.

We made our review pursuant to the Buciget ar.a Accounting Act, 1921 ( 31 U.S.C. 53), and the Accounting and Auditing Act of 1950 (31 U.S.C. 67).

We are sending copies of this report to the Director, Office of Management and Budget, and the Administrator, Energy Research and Development Administration.

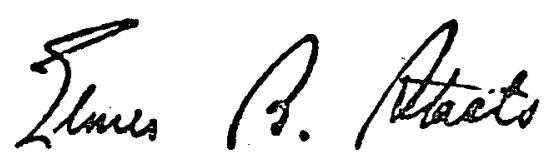

Comptroller General of the United States 
DIGEST

CHAPTER

THE LIQUID METAL FAST BREEDER REACTOR

PROGRAM--ORIGIN AND EVOLUTION

Why and when is LMFBR expected to be needed

How did LMFBR evolve to its current status?

The approach to commercialization of LMF BR

How much will it cost to develop LMFBR?

Who is involved in the LMFBR procram? 12

ELEMENTS AND FACILITIES MAKING UP THE LMFBR PROGRAM

Reactor physics

Fuels and materials

Fuel recycle

Safety

Componerit development

Planc experience

Facilities used in the LMFBR program

managelient of the lmFBr program

Management control system within RRD 27

Conclusion

CRBR project organization 31

4

FUNDING FOR ENERGY RESEARCH AND DEVELOPMENT 33

Proposed fiscal year 1976 energy R\&D program

LMFBR program funding

FOREIGN LMFBR PROGRAMS

Status of the major LMFBR programs 36

Comparison of U.S. program with foreign programs

AEC assessment of the French LMFBR program

ERDA review group assessment of potential use of foreign programs 42

Hatters for consideration by the Congress

6 - SCOPE OF REVIEW 


\section{Contents}

Page

A.PPENDIX

I

LMFBR program cost projections (1975 through 2020) LMFBR introduction

date -1987

II

LMFBR program major participants by program area

III LMFBR program facility relationships 48

IV LMFBR program major facilities by proaram area

$\checkmark$ Schedule of ERDA-funded facilities used in support of the LMEBF pregram Current LMFBR program sidpport facilities Plarined LMFBR program sipport facilities Other facilities involved in the I,MFBR program

$$
\text { Reactor Research and Development Division }
$$

VII CRBR project management organization chart

VIII Principal officials of AEC and ERDA responsible for administering the activities discussed in this report

\section{ABBREVIATIONS}

AEC Atomic Energy Commission

CRBR

EBR

Clinch River Breeder Reactor

ERDA

FFTF

GAO

LMFBR

NCBR

$R \& D$

RRD

Experimental Breeder Reactor

Energy Research and Development Administration Fast Flux Test Facility

General Accounting Office

Liguid Metal Fast Breeder Reactor

Near Commercial Breeder Reactor

Research and Development

Reactor Research and Development Division 
COMPTROLLER GENERAL'S

REPORT TO THE CONGRESS

$\underline{D} \underline{I} \underline{G} \underline{E} \underline{S}$

WHY THE REVIEW WAS MADE

The 1 iquid metal fast breeder reactor is our Nation's highest priority energy program. A breeder reactor can create for the future more fuel than it uses.

Because of the intense congressional and pubiic interest in this breeder and the very large amounts of Government and private funds that have been and are expected to be spent to develop it, GAO wanted to know how the breeder program started, where it is today, and where it is going.

GAO will release shortly a report on the cost and schedule estimates for the first breeder demonstration plant, and an issue paper on the broad range of promises and uncertainties of the total breeder program.

\section{FINDINGS AND COINCLUSIONS}

The Energy Research and Developmenc Administration (ERDA)-- the successor agency to the recentiy abolished Atomic Energy Commission (AEC)-envisions that operation of the first large commercial breeder will begin in 1987--a target date which has slipped 3 years since 1969. ERDA expects to subsidize this first commercial plant. ERDA projects that by the year 2000,186 commerclal-size breeders will be built and operating, some of which might also require subsidies. However, there are indications that these ERDA projections are optimistic. (See pp. 2 to 4.$)$
THE LIQUID METAL :AST BREEDER REACTOR PROGRAM--PAST, PRESENT, AND FUTURE

Energy Research and Development Administration

ERDA's approach to conmercializing breeders includes building a demonstration plant to show that a breeder can operate safely, cleanly, and reliably. Plans to build the Nation's first breeder demonstration plant are now in the preliminary design stage. (See p. 7.)

Until recentiy, the ireeder program stressed the progressive development of six successively larger demonstration plants. This approach would have required considerable Government support to develop larger components for each successive demonstration plant. In mid1974, AEC realized that this approach piaced too much emphasis on plant construction and operation and not enough on developing plant components.

Consequently, AEC terminated plans for all but one demonstration plant and decided to build instead a facility to test large components. This major redirection places the single demonstration plant in a very important position. (See pp. 8 and 9.)

AEC's total breeder program furiding through fiscal year 1974 was about $\$ 1.8$ billion. Recent estimates show that an additional $\$ 8.9$ billion (fiscal year 1975 and 1976 dollars) will be needed to carry the program through to 2020. Since 1968 the expected costs of the program have increased by $\$ 6.8$ billion, $\$ 3.5$ billion of which ERDA attributes to inflation. (See pp. 9 to 11.) 
The recent cost estimate includes $\$ 300$ million for Government subsidy of one plant after the demonstration plant. This cost estimate assumes that major design and construction improvements would be realized after the demonstration piant.

ERDA officials told GAO that based on other analyses ERDA and its contractors have made; the sutsidy could be as high as $\$ 2$ biliion for several plants if the program does not attain its development goals and resuiting improvements and if more conservative assumptions are made. (See p. 11.)

In addition to Federal funding of the breeder, over half a billion dollars of private funds have beell or will be spent over the next 5 to 10 urs to develop the breeder and build the demonstration plant. (See pp. 11 and 12.)

Elements and facilities making up the breeder program

The overall breeder program consists of six major program areas, each of which contributes an important. element of technology. Within the fuels and materials area, there is a potential problem concerning the continued availability of qualified comercial fabricators of breeder fuel. (Sec pp. 15 to 18.)

The fuel recycle area is probably the least technologically advanced area at this time. The ability to recycle plutonium for use in the breeder is essential to the breeder concept. The Vuclear Regulatory Commission is presently considering the quas ion of allowing recycling of plutonium in lightwater reactors. The Commission's decisicn, expected in late 1977 or early 1978, could have an adverse effect on the breeder program. (See pp. 18 and 19.)

Each area has at least one major test facility. GAO identified 22 major facilities in use or being built in support of the program. ERDA pians to build eight more major facilities. The estimated cost of all these facilities is about $\$ 3$ billion, which is includec' in the breeder program cost estimate. (See pp. 15 and 24.)

Three of the most important facilities have experienced substantial cost increases and schedule delays.

For example, a facility to test breeder fuels was originally estimated in 1967 to cost $\$ 87.5$ million to construct and was to begin operations early in 1974. This test iacility is now forecast to cost $\$ 512$ million and operations are expected to begin early in 1980. The other two facilities have also ex. rienced cost increases of over 100 percent as well as schedule delays. (See pp. 25 and 26.)

Management of ERDA's breeder program

The ERDA division that manages the breeder program had been experiencing delays in reaching agreement on programmatic and technical matters affecting the program and needed to keep top management better informed of problem areas. The division recognized these problems and contracted with a private consulting firm to identify ways to improve management control.

As a result, the division is implementing a new system for administering, managing, and controlling its various programs, of which the breeder is the most important. This 
system is iritendet to provide increased program visibility and control.

If properly implemented, the new system should reasonably assure that ERDA will have greater visibility over the LIFB? prograin and that it will be in a position to better focus mariagement attention and direction over those areas of the program experiencing croblems. (See pp. 27 to 31.)

The demonstration plant project, the Clinch River Breeder Reactor, is managed jointly by ERDA and utility industry participants. This manaoement arrangement is complex and potentially cumbersome. Project officials say no problems have resulted thus far from this complex arrangement because of the compatible personalities of the two individuals most directly involved in managing the project. (See pD. 37 and 32.)

In GAO's view, the organizational arrangement for the demonstration plant project, which depends heavily upon the personalities of the individuals involved, may prove to be so cumbersome as to hinder the effective management of the design and construction of the Clinch River Breedei Reactor and consequently represents a potential risk to the project. An ERDA review group reached similar conclusions.

The breeder demonstration project is now estimated to cost the Government about $\$ 1.468$ billion- $\$ 1$ blllion more than was estimated several years ago. GAO believes that now, when the Government is expected to commit an additional $\$ 1$ billion to the project, may be an appropriate time to seek a change in the present contractual arrangement to strengthen and steamline
Government control over the project. (See p. 32.)

On March 10, 1975, ERDA submitted to the voint Committee on Atomic Energy for its approval proposed leqisiation and underlying documents that would provide for a new management structure for the project. Essentially, management control of the aroject would be given to ERIA, commensurate with the Governme it's investment in the project. This :ew management structure is intended to strengthen and streamlire Government controi over the project.

In a recent report, GAO pointed out that the various documents ERDA submitted to the Joint Committee did not clearly delineate the manner in which the project would be managed and that ERCA might not be able to exercise usual management prerogatives. (See p. 32.)

Relation to breeder funciing tc total Federal energy funding

Federal energy research and development funding has grown markedly since fisca? year 1971 when it was $\$ 420$ million. The proposed fiscal year i976 Federal budget includes $\$ 1.8$ billion for energy research and development. (Seepp. 33 and 34.)

Federal funding for developing the breeder was $\$ 168$ million in fiscal year. 1971 , representing 40 fercent of total Federal energy research and development funding. In fiscal year 1976, funding for the breeder is estimated to be $\$ 474$ million, about 26 percent of total Federal energy research and development funding. (See p. 35.)

For ign breeder programs

Deveioding a liquid metal fast 
breeder is a high priority national energy program of five other major industrial nations: United Kingdom, France, Japan, West Germany, and the Soviet Union. EROA says that, of the fortign programs, those of the Soviet Union and France are probably the most advanced in reactor development. (See pp. 36 to 39.)

Although there are some differences between the L.S. and foreign programs, all foreign programs either contain or plan many of the same elements that are in the longrange U.S. program. (See p. 40.)

A contributing factor in the rapid advance of the rrench program, ERDA says, has been the less stringent safety requirements in France. ERDA says that French breeder reactors would have a difficult time getting licensed in the United States, a) though the licenseability of Frencii reactors has not been explored in the United States. (See pp. 40 to 42 .)

An ERDA review group report said foreign breeder programs can contribute important data and infor- mation to the U.S. program. The U.S. program could make use of foreign programs under several specific arrangements; however, none of these arrangements could save any large amourit of U.S. effort. (See p. 42.)

RECOMMEIDATIONS AND SUGGESTIONS

This report contains no recumendations.

AGENCY ACTIONS AND UNRESOLVED ISSUES

GAO discussed this report wit: ERDA officials on severai ( . . ins and believes that there a $\cdots$ major residual differences in ${ }^{r} t$.

MATTERS FOR CONSIDERATION BY THE CONGRESS

If the Congress wants to krow whether greater reliance can be placed on the use of foreign liquid metal fast breeder reactor technoiogy, it should explore with ERDA in greater depth the advantages and disadvantages of using foreign liquid metal fast breeder reactor technology. 


\section{CHAPTER}

THE I IOUID METAL FAST BREEDER REACTOR

PROGRAM =-ORIGIN AND EVOEUTION

A breeder reactor, such as the Liquid Metal Fast Breeder Reactor (LMFBR) ${ }^{1}$, can create more fliel than it uses. Because of this reature, developing a commercial LMFBR is the aim of the Nation's highest priority energy program. Efforts to develop the LMFBR concept have cost the Federal Government about $\$ 1.8$ billion. The Energy Research and Development Administration (ERDA) ${ }^{2}$--successor agency to the Atomic Eneray Commission (AEC)--projects that it will cost an additional $\$ 8.9$ billion through the year 2020 .

WHY AND WHEN IS LMFBR EXPECTED TO BE NEEDED

The growing shortage of fossil fuels is spurring the search for alternate sources of energy. Nuclear power reactors, using enriched uranium as a fuel, are an alternative to fossil fuels for generating electricity. ERDA predicts that the U.S. electrical energy demand will double between 1970 and 1985 and will double again by the year 2000 . Nurlear power presently accounts for about 6 Dercent of the total U.S. electrical generating capacity. ERDA expects nuclear power will account for about 60 percent by the year 2000 .

Currently, 53 commercial nuclear power plants are onerating in the United states. Ore is a high temperature qascooled reactor and the rest are light-water cooled reactors. All of the currently operating nuclear reactors consume fuel during the energy producing process. Because of the limited supply of low-cost uranium ore available for fuel in such

${ }^{1}$ Liquid metal refers to the liquid sodium used as the coolant to carry off the heat of the reactor fuel. A fast reactor is a reactor in which the chain reaction is sustained primarily by fast neutrons rather than by the slower speed neutrons found in present qeneration commercial nuclear power reactors.

${ }^{2}$ The Energy Reorganization Act of 1974 (Public Law 93-438) abolished AEC and established the Energy Research and Development Administration and the Nuclear Regulatory Commission on January 19, 1975. All of the AEC programs and activities discussed in this report are now carried out by the Energy Research and Development Administration and the Nuclear Regulatory Commission. 
reactors, ERDA has excressed the belief thit the full potential of nuclear energy for the future can be realized nnly by developing the breeder reactor because (l) the know economically recoverable domest ic uranium reserves (approximately 700,000 tons) will be committed to light-water reactcrs within a few years and (2) complete reliance on light-water reactors will deplete these estimated reserves in about 25 to 50 years.

Light-water reactors use only about 2 percent of the energy available in the nuclear fuel they use. Fast breeder reactors, on the other hand, can use as much as 60 percent or more of the total energy from the nuclear fuel and, at the same time, create more fuel for future use than they use.

ERDA is developing several types of breeder reactors: (1) the molten salt breeder, (2) the liqht-water breeder, (3) the gas-cooled fast breeder, and (4) the LMFBR. The LMFBR has been the highest priority breeder program since the mid-1960s.

\section{Program schedule}

The present LMFBR program schedule calls for rommeicial introduction of the LMFBR in 1987. ERDA defines comercial introduction as that point in time that one large-suale breeder reactor becomes operational. ERDA recognizes that this reactor would not be of the same power level as later reactors and that it would require some form of Government subsidy. In addition, under the present plan, ERDA is projecting that $\delta$ breeder reactors would be built in the late $1980 \mathrm{~s}$ and large numbers would be built in the early $1990 \mathrm{~s}$. Some of these reactors may require additional Government subsidies.

ERDA officials emphasized, however, that ERDA's Administrator is still formulating plans for the LMFBR arid, as of March 1975, he had not reached a final position on the proaram.

ERDA anticipates that during the early 1990 s a viable and competitive commercial industry can be developed. A viable i.aduscry will include reactor manufacturers and. architect-engineers from whom interested utilities can solicit bids and select a power plant. A competitive industry will include a number of qualified and experienced vendors from whom selections can be made for furnishing major equipment iteme.

AEC projected that, by the year 2000,186 commercialsize IMFBRs will be built and operating. These piojections were derived from a cost-benefit analysis contained in the Proposed Final Environmental Statement on the LMFBR program, 
which AEC released for public cominent in Januarv 1975. The following chart shovs the number of LMFBRs exrected to beain operations through the year 2019 .

$\begin{array}{crr}\text { Year } & \begin{array}{c}\text { Number of plants } \\ \text { that beginoperations }\end{array} & \begin{array}{r}\text { Cumulative } \\ \text { or olants }\end{array} \\ 1986-87 & 1 & 1 \\ 1538-89 & 8 & 22 \\ 1990-91 & 13 & 46 \\ 1992-93 & 24 & 80 \\ 1994-95 & 34 & 126 \\ 1996-97 & 46 & 186 \\ 1998-99 & 60 & 1,178 \\ 2000-19 & 992 & \end{array}$

The Proposed Final Environmental statement points nut, however, that general schedule slippages in U.S. utilities' plans for added electrical generating capacity

$" *$ * * suggests that the assumed timing of conmercial breeder introduction should also be slipped, resesumably into the early 1990s, insteac of the late $1980 \mathrm{~s}$ as previously assumed."

Our discussions with representatives of the litility industry and reactor equipment manufacturers indicace that ERDA's projections for the number of LMFERs in tive iate $198 \mathrm{~ns}$ and early 1990 s is optimisic and possibl: unrealistic. These representatives expressed the view that few utilities would be willing to commit larre amounts of capital until liney were fairly certain that LMFBRs woldd be technically and economisally $\because$ iáble.

Building reactors in the United states from time of commitment to oreration presently requires about 8 to 10 years. To meet ERDA's projections, utilities would be reguired to commit large amounts of capital in the late l970s or early $1980 \mathrm{~s}-$-which is at least several vears before ERDA expects to have developed and tested the major components reauired for commercial-size LMFBRs. It is also up to 10 years prior to the expected 1987 operation of the first commercial-size LMFBR, which ERDA believes will confirill the economic viability of commercial-size LMFBRs.

In a 1969 cost-benefit study of the breeder program, LMFBR's introduction date was predicted to be 1984,3 years earlier than the present scheduie. AEC attributed this 3ycar schedule slip to (1) delays in neqotiating contracts for and getting congressional authorization for the LMFBR demonstration plant project (Clinch River Breeder Reactor) and (2) such external factors as delays in light-water re- 
actor licensing and the court-imposed requirement to issue an environmental impact statemeni: on the overall LMFBR program.

In October $1974,4 E C$ requested that a special staff study be made of the LMFBR program. In part, the review was to reassess the need for and timing of the LMFBR in light of the latest available information. The review group concluded that, because of the limited amount of known economically recoverable domestic uranium reserves, LMFBR's development is needed to insure the continued availability of the nuclear power option to meet the Nation's future enerqy needs. The group recommended that the LMFBR program should proceed expeditiously toward the goal of a commercial breeder by the early l990s. They also recommended that an aqgressive, accelerated effort be undertaken to better define the likely availability and producibility of economic uranium resources in the United States. The group said that the LMFBR program should be reassessed as additional resource data becomes available.

HOW DID LMEBR EVOLVE TO I TS CURRENT $\bar{T} \overline{T A} \bar{T} U S ?$

Interest in fast breeder reactors dates back to the early 1940s. Nuclear scientist Enrico Fermi first demonstrated the concept in experiments at the University of Chicago. His experiments produced the first apparent evidence that breeding nuclear fuel was possible. The reactor used in these experiments was the first facility to successfully show a self-sustaining nuclear chain reaction on December 2, 1942. The phenomenon opened the doors to the development of the nuclear power industry.

Because expert atomic scientists and uranium resources were devoted to developing the atomic bomb for use in world War II, the national laboratories were not able to devote full attention to the breeder reactor. After the war, the nuclear scientific community increased its effort toward breeder :eactor development. AEC was formed in 1946 to develop and manage atomic energy activities "in the United st.ates.

At first, AEC considered various breeder programs. The Clementine reactor at Los $A$ lamos Scientific Laboratory. in New Mexico was one of the earliest steps towards the advancement of the breeder concept. It operated from 1946 to 1953 and was used to explore the possibilities of operating a fast reactor with plutonium fuel and a liguid mecal (mercury) as a coolant. This first experimiental reactor proved that fast reactors could operate safely and reliably. 
The next significant event was the construction and operation of the Experimental Breeder Reactor I (EBR-I) by Argonne National Laboratory at its test site in Idaho. On December 20, 1951, this Eacility produced the world's first electricity from nuclear fuel. EBR-I proved the feasibility of the breeding concept.

Dirring the operation of EBR-I, the next sianificant step occurred--the design and construction of Experimental Breeder Reactor II (EBR-II) by Argonne National Laboratory at its Idaho test site. Construction of this facility beqan in 1.958 and operations began in 1963. EBR-II was to determine the feasibility of (1) using a fast reactor with a sodiuh coolant as a central station nlant and (2) developing a fuel recycle capability for reprocessing used (or spent) fuel from the reactor to remove certain radioactive products, refabricating the fuel into new fuel, and placing it back in the reactor for continuing operations. In 1965, EBR-II's primary purpose was changed to its present role--to testing fuels and materials for the LMFBR program. EBR-II is the only operating ireeder reactor in the united states.

In early 1955, AEC invited proposals from orivate industry to design, construct, and operate a power reactor as part of AEC's 5-year reactor development procram. Construction of this reactor--called the Enrico Fermi Atomic Power Plant--becan in 1956 and critical operations began. in 1963. This was the Nation's first privately owned and operated fast breeder reactor; however, AEC provided sone financial assistance to industry for this project. The plant operated until late 1972 and produced 32,000 megawat 1 hours of commrrcial electricity.

The development of LMFBR technology through the early and mid-1960s resulted in identifying certain problem areas needing resolution. To find solutions to the oroblems, various facilities were or are being built, including the: (1) Los Alamos Molten Plutonium Experiment, (2) Southwest Experimental Fast Oxide Reactor, and (3) Fast Flux rest Facility (FFTF). All three were or are special purpose reactors built Eor specific types of experiments. For example, the southwest Experimental Fast oxide Reactor was designed to demonstrate inherent safety characteristics of a particular type of LMFBR fuel. Other special purpose facilities--the Nuclear instrument Test Facility and the Radioactive sodium Chemistry Loop-which supported LMFBR were also built at this time.

In 1967, AEC issued a report to the president which described the breeder's promise of meeting the Nation's long-

$I_{A}$ unit of power; equal to $1,000,000$ watts. 
term energy needs and established the LMFBR program as its highest priority civilian reactor development effort. LMFBR was chosen over other breeder concepts because of (1) its potential favorable performance and economy, (2) interest and support by reactor manufacturers and electric utilities, (3) the amount of base technoloqy and operating experience already available, and (4) proven basic feasibility. AEC stated that these factors provided the basis for LMFERs to realize a relatively short development-to-commercialization time period.

From 1965 to 1967, the electric utility industry started making large scale commitments to rely on nuclear power plants fo: much of the auditional electrical capability our country needed. These commitments involved primarily constructing and operating light-water reactor power plants.

The increased electrical consumption during the late 1960 s and early 1970 s resulted in brownouts in major cities across the country. Fossil fuel prices rose sharply and some major utilities' levels of existing fuel reserves decreased. As a result, the President directed that a special review of the national energy situation be made. This review was to identify possible approaches the Federal Government could take to alleviate the potential shortages of fuel and to help insure that enough fuel existed for future use.

The results of the review were reflected in the president's Energy Message to the Congress in June 1971. In this message, the president established the LMFBR orogram as the Nation's highest priority energy program and made a national commitment to successfully demonstrate the concept by 1980 . According to AEC, the national priority placed on developing LMFBR was needed to take full advantage of the momentum and technical progress achieved up to that time and to get the funding required to demonstrate the concept.

In 1973, the president reemphasized the national enerqy supply problem and established Project Independence. The current objective of Project Independence is to achieve invulnerability to changes in foreign production and shipment of energy supplies. This places even more importance on developing new energy sources, like LMFBR.

\section{THE APPROACH TO COMMERCIALIZATION}

\section{OF LMFBR}

The basic objective of the LMFBR program is to develop a broad technological and engineering base with extensive utility and industrial involvement which will lead to a strong. competitive, commercial breeder industry. The long- 
term goal for the program is to establish a breeder reactor econony early in the 2 lst century which will furnish all the material needed to fuel nuclear plants to meet our total electrical energy demand.

AEC's approach to the commercialization of LMFBRs has been proceeding along two lines of effort--the base technology program and the demonstration plant program. Under the base technology program, emphas is is placed on developing key technical areas. Engineering development, manufacturing, and proof testing efforts have been and are being expanded within this part of the program. These efforts are performed with private industry and are directed at developing realistic technical and economic bases for the LMFBR demonstration program.

The demonstration piant program is to serve as the key to the program's transition from the technology development phase to large-scale commercial utilization. Pians for building the Nation's first LMFBR demonstration plant--the Clinch River Breeder Reactor (CRBR) near Oak Ridae, Tennessee--are now in the preliminary design stages. This facility is to be a 350 megawatt electric (MWe) ${ }^{1}$ powerplayt and is presently scheduled to be operational by mid-1982. It is a cooperative government/industry effort. CRBR's primary objectives are to

--demonstrate the safe, clean, and reliable operation of an LMFBR closely resembling a commercial-sized plant while showing a high availability factor for power production in a utility environment,

--serve as the focal point for the development of systems and components,

--develop industrial and utility capabilities to design, construct, and operate LMFBRs, anc.

--demonstrate the commercial licenseability of LMFBRs.

Acrording to AEC, constructing and operating an LMFBR demonstration plant is the only means by which these objectives can be realized. The guidelines issued in establishing CRBR as it presently exists were based on utility recommendations.

$I_{A}$ megawatt electric is a measure of electric power while a megawatt thermal ( $M W t$ ) is a neasure of heat. For present generation nuclear powerplants, about 3 MWt are required for each MWe produced. 
AEC considered other approaches to realizing these same objectives, including trying to encourage industry ic undertake the cemonstration of LMFBR technology on its own, relying on foreign experience to demonstrate the concept, and purchasing foreign LMFBR technology and adopting it to the prevailing U.S. regulatory requirements. AEC pointed out, however, that none of the alternatives was able to meet the objectives satisfactorily.

Until mid-1974, AEC had strossed the progressive development of successively larger demonstration and "early commercial" plants, 1 using these olants as test beds for component development. AEC projected that two more demonstration plants and three early commercial plants would be built after CRBR. These plants were expected to show the reliability, safety, licenseability, and environmentei acceptability of the LMFBR concept and would provide private industry with a reliable basis on which to build an LMFBR energy economy. This approach would reguire considerable Government support ior developing larger sodium components, such as steam qenerators, pumps, valves, piping, and heat exchangers for each successive demorstration plant.

As a result of an assessment of the LMFBR program made in mid-1974, AEC--along with industry, AEC national laboratories, and utility executives--identified a severe program imbalance. AEC realized that building a number of successively larger demonstration plants placed too much emphasis on developing plant components for each successive plant. This approach would have required development of several generations of large components--a costly and time consuming process. ERDA officials believe that component development concurrent with plant construction has been a probable cause of the delays experienced thus far in the construction of FFTF and that this approach could delay construction of CRBR.

Consequently, in July 1974, AEC made a major redirection to its LMFBR program. The redirection called for terminating plans for multiple demonstration plants and going with only a single demonstration plant--CRBR. Instead of follow-on demonstration and early commercial plants, a large component test facility--Plant Component Test Facility--is now planned to test full commercial-size sodium components. Early plant experience is expected to be gained by operating FFTF and CRBR in the united states as well as from foreign

loperating LMFBR plants smaller in size and power generating capacity than future commercial LMFBR plants are anticipated to be. 
LMFBR programs. One near commercial plant ${ }^{l}$ is planned to cover any further needs in the plant experience area. It is expected to be about 1,000 to 1,500 MWe in size and to consist of the large commercial-size components to be developed and tested under the component development portion of the LMFBR program.

With this revised program, CRBR is placed in an even more important position; it will now be depended upon to demonstrate the reliability, safety, licenseability, and environmental acceptability of the LMFBR concept. Also, CRBR will serve as a focal point for developing components and systems. In this capacity it should provide major input to the large component development programs and the testing requirements which must be factored into the design of the plant Component Test Facility. This facility is planned to become operational in the early $1900 \mathrm{~s}$.

According to ERDA, the availability of the Plant component Test Facility should allow industry to construct

large commercial-size components much sooner than previously contemplated. ERDA has stated that this adjusted LMFBR plan should further enhance the ability of industry to design and build a number of large commercial plants for operation by the late 1980s or early 1990s.

HOW MUCH WILL IT COST

TO DEVELOP LMFBR?

AEC's total LMFPR program funding from fiscal year 1948 through fiscal yeat $19 / 4$ was about $\$ 1.8$ billion. ERDA recently estimated that an additional $\$ 8.9$ billion (fiscal year 1975 and 1976 doilars--effects of inflation for fiscal years after 1976 are not included) will be needed to carry the proqram through to $2020--m a k i n g$ a total program cost of $\$ 10.7$ billion. The following chart summarizes the LMFBR costs through fiscal year 1974 and projections through fiscal year 2020. A more detailed chart showing projected program costs for fiscal years 1975 to 2020 is included in appendix I.

${ }^{1}$ One which has full-size commercial plant components and features; it may be at a lower power level than a commercial plant. 
LMFBR Progra

\begin{tabular}{|c|c|c|c|}
\hline & & FY 75 & \\
\hline Thru & & to & \\
\hline (actuar $\frac{F}{1)}$ & $\begin{array}{c}\frac{F Y}{F} \frac{75}{75} \\
\text { dollars) }\end{array}$ & $\begin{array}{l}\text { (FY } \bar{Y}-\frac{20}{75} \frac{20}{7} \overline{6} \\
\text { do } 11 \text { ars })\end{array}$ & Total \\
\hline
\end{tabular}

\begin{tabular}{|c|c|c|c|c|}
\hline Operating & & & & \\
\hline $\begin{array}{l}\text { Reactor physics } \\
\text { Fuels and }\end{array}$ & 119 & $\$ 11$ & 162 & 281 \\
\hline materials & 619 & 114 & 1,816 & 2,435 \\
\hline Fuel recycle & 15 & 6 & 507 & 522 \\
\hline Safety & 97 & 36 & 1,023 & 1,120 \\
\hline Components & 470 & 88 & 2,021 & 2,491 \\
\hline Plant experience & -30 & -56 & 1,489 & $-1,519$ \\
\hline Subtotal & 1,350 & 31.1 & 7,018 & 8,368 \\
\hline $\begin{array}{l}\text { Capital equipment } \\
\text { Construction }\end{array}$ & $\begin{array}{r}66 \\
379\end{array}$ & 23 & $\begin{array}{r}424 \\
\end{array}$ & $\begin{array}{r}490 \\
810\end{array}$ \\
\hline COHSLIUCLIOUI & 319 & 141 & $-1+431$ & $\ldots 1,810$ \\
\hline Total & $\$ 1,795$ & $\$ 481$ & $\$ 8,873$ & $\$ 10,668$ \\
\hline
\end{tabular}

In a 1969 AEC study entitled "Cost-Benefit Analysis of the U.S. Breeder Program," AEC projected for the first time the expected research and development costs for the LMFBR program. The costs through 2020 were estimated to be about $\$ 3.9$ billion. Thus, since 1968, the expected costs of the LMFBR program have increased by about $\$ 0.8$ billion, nearly a tiareefold increase.

Based on a recent ERDA study comparing the trio estimates, $\$ 3.5$ billion of the $\$ 6.8$ billion increase was due to inflation through fiscal year 1976. The remaining $\$ 3.3$ billion increase was due to changes in the scope of the program, including increased costs associated with the FFrF project ( $\$ 660 \mathrm{million})$, CRBR project ( $\$ 670 \mathrm{mill}$ ion), increased large component development program $(\$ 1,120 \mathrm{million}$, fuel development program ( $\$ 450 \mathrm{million})$, and safety program (\$l40 million), and capital equipment and miscellaneous ( $\$ 220 \mathrm{million}$ ).

These cost estimates do not include the amounts spent by AEC's regulatory organization or the amounts to be spent by the successor agency--the Nuclear Regulatory Commission-to meet their licensing and related responsibilities pertaining to the LMFBR program. AEC's regulatory organization spent about $\$ 2.2 \mathrm{mill}$ ion in fiscal year 1973 and 1974 and the Nuclear Regulatory Commission expects to spend $\$ 22.7 \mathrm{mill}$ ion during fiscal years 1975 through 1980 on LMFBR related work. 
The costs for proqram direction and administration by ERDA emplovees are not included in the LMFBR proaram cost estimate. ERDA does not charge anv of its research proarams, including the LMFBR, with reaulatory costs or with the costs of directing and administering oroarams by its employees. This treatment is consistent with ERDA's buaget justification to the Congress, where pronram direction and administration costs are also considered separately rather than allocated to other programs and activities. However, administrative costs of contractors engaged in the LMFBR proaram are included in the costs of that proqram.

A major question that could sianificantly increase the projected LMFBR prooram cost involves the number of LilFBR plants needed after CRBR for the LMFBP total nower costs to become competitive with lioht-water reactor costs. AEC's LMFBR program cost estimate includes $\$ 300 \mathrm{million}$ for a Government subsidy of one plant after CRBR. ERDA officials said, however, that there is a areat deal of uncertaintv regarding (l) the amount of subsidv that will be necessarv for the first plant after CRBR and (2) whether subsidies will be necessary for additional olants. The officials exrlained that much of this uncertainty stems from whether desian and construction improvements can be realized after CRBR. The estimate that only one plant after CRBR would require a subsidy of $\$ 300 \mathrm{milli}$ ion is based on the assumption that such design ano construction improvements would be sianificant.

ERDA officials told us that based on other analyses ERDA and its contractors have made, this amount could be as high as $\$ 2$ billion for several blants if the program does not attain its development goals and resultina improvements and if more conservative assumptions are made.

Cost of privately funded research and development

In addition to AEC-ERDA fundina, a considerable amount of privately funded research and development effort is devoted to the LMFBR program. Reactor manufacturers, such as Atomics International, a Division of Rockwell International; Babccck and Wilcox; Combustion Enqineering, Inc.; General Electric Company; and Westinghouse Electric Corporation have spent more than $\$ 80 \mathrm{million}$ for privately funded research and development on LMFBR through 1974. According to company representatives, these companies expect to spend more than $\$ 225$ million over the next 5 years (1975 through $1979)$.

The electric utility industry is also contributing to the LMFBR program. As of February 1975, more than 700 
electric utilities and cooperatives have pledged $\$ 257 \mathrm{mil}$ lion to support CRBR. Th is represents the largest single commitment to a research and development project ever undertaken by the electric utility industry.

WHO IS INVOLVED IN THE LMEBR PROGRAM?

Carrying out the LMFBR program involves many varied participants from Eederally owred, contractor-operated laboratories to private industrial firms and universities. As of September 1974, 49 AEC prime contractors and major subcontractors were participating in the LMFBR program. Fiscal year 1974 staffing data illustrate the amount of resources that have been used in the program. In that year, 2,693 direct professional staff-years of effort were spent by AEC laborator: and con'.ractor personnel. This amounts to 79 percent of the totai 3,413 direct professional staff-years spent at these same locations to support AEC's civilian reactor development program, which includes the LMFBR program. Appendix II shows the major program participants by LAFBR program area.

National laboratories and engineering centers

ERDA oversees a number of Government-owned laboratories that are operated by contractor organizations representing universities, cther nonprofit organizations, and private industry. There are 32 such facilities throughout the country, excluding production ard nuclear weapons fabrication facilities. These laboratories have built up a diversity of scientific and technical resources and plant facilities.

\section{Major ERDA Laboratories and Encineer ing Centers and The ir Major Areas of Responsibilities in support of the LMF BR Prog $r$ am}

ERDA facility and location

1. Argonne National Laboratory, Chicago, Illino is

2. Hanford Engineering Development Laboratory, Richland, washington

3. Liquid Metal Engineering Center, Santa Susana, California
Area of responsibility

Fuels and materials, physics and safety research, and component eng ineering activities

Fuels and materials and core development activities

Component and instrumentation development 
4. Holifield National Laboratory, Oak Ridge, Tennessee
Safety, fuel recycle, and component development

Argonne National Laboratory, which devotes a major portion of its effort to the LMFBR program, has the only operating breeder reactor in the United States--EBR-II. Although Argonne is primarily responsible for LMFBR safety programs, it also carries out basic studies and applied technology work in the fields of reactor physics, fuel and materials development, and component engineering.

Hanford Engineering Development Laboratory is the site of the key engineering development laboratory for the LMFBR program. Its initial missior: is to manage the development, design, coristruction, and startup of FFTF, which it will then operate. This laboratory is largely responsible for examining, developing, and fabricating fuels, materials, and cladding: for developing reactor component and instrumentation and sodium technology; and for materials management and safeguards.

The Liquid Metal Eng ineering Center is a complex of liquid sodium facilities for testing and evaluating components such as heat exchanges, steam generators, valves, piping, pumps, flowmeters, and other mechanical elements for breeder reactors.

Although Holifield National Laboratory is involved in all LMFBR program areas except plant experience, it is primarily involved in the safety program and the development of LMFBR design and engineering standards. Remote handiing operations for LMFBR fuel and strurtiral design methods are two other essential elements of its program.

Otner ERDA laboratories also participate in the development of LMFBR, but to a lesser extent. Some of these are the Los Alamos Scientific Laboratory at Los Alamos, New Mexicc; the Pacific Northwest Laboratory at Richland, Washington; and the Idaho National Engineering Laboratory at Idaho Falls, Idaho.

Private industry

Private industry's involvement in the developmental stages of the LMFBR program is essential for meeting the program objective of establishing a timely capability for a commercially competitive breeder program. Construction activities undertaken as part of the LMFBR testing and technology development program (e.g.. Sodium Pump Test Facility, FFTF, High Temperature Sodium Facility) have provided the industrial sector of the nuclear community with large-scale involvement with LMFBR technology. Various private industrial firms, 
under contract to ERDA, do research and development work for the base LMFBR program.

Atomics International, a Division of Rockwell International, General Electric Company, and Westinghouse Electric Corporation are the chief industrial organizations involved in the program. All three are major participants on the CRBR demonstration project. Westinghouse is the lead reactor manufacturer responsible for integrating the entire nuclear portion of the plant. Atomics International and General Electric are heavily involved in the component development area of the base LMFBR program, and they also do some work in the safety and fuels and materials areas. Most of. Westinghouse's effort for the base LMFBR technology proaram is in the component development and fuels and materials area. Westinghouse is also the FFTF reactor plant designer. Atomics International operates the Liguid Metal Engineering Center for ERDA.

The LMFBR program's high priority and the amount of money to be spent on it has generated a great deal of conqressional and public interest in the program. The following chapters of this report discuss several aspects of LMFBR for which a great deal of interest has been expressed. These aspects are the

--elements and facilities making up the oroqran,

--management structure of the program,

--relative funding emphasis of the LMFBR program, and

--LMFBR programs of foreign nations. 


\section{CHAPTER 2 \\ ELEMENTS AND FACILITIES MAKING UP \\ THE $\mathrm{LMFBR}$ PROGRAM}

The LMFBR program consists of six major program areas, each of which contributes an important element of technoloqv. To realize the overall objective of commercializing LMFBR, each area must be successfully completed. According to ERDA, none of these areas has been sufficiently developed to support a commercial plant at this time. The six areas are

-reactor physics,

--fuels and materials,

--fuel recycle,

- safety.

--component developmeit, and

--plant experience.

Each program area has at least one major test or demonstration facility which provides a major contribution to the LMFBR commercialization objective. The relationship these facilities and proqram areas is shown in appendix III. For the most part, these are Government-owned and contractoroperated facijities. They have been built up over $t$ ime and represent large capital investment by the Government. Many of the facilities are at the various national laboratories but some are at other contractor locations.

\section{REACTOR PHYSICS}

This program area's objective is to develop desiqn data, experimental procedures, and analytical methods adequate to insure the safe and economic performance of commercial LMFBRs. The Zero Power Plutonium Reactor in Idajo is the princjpal experimentai facility for this area. It is presently being modified so it will be able to handle experiments for reactor cores in the commercial size ranqe. According to ERDA, this is the most technologically advanced area.

\section{FUELS AND MATERIALS}

This area is centered on developing a reliable, safe, and economic fuel system design. Efforts are being made to improve fuels and materials for near terin needs and to develop advanced fuels and materials which are necessary if LMrBR is 
to reach its full potential for resource conservation and economic viability. A mixed-oxidel fuel design will be used as the initial fuel for FFTF and CRBR and could also be used in a commercial plant. But improved and advanced fuels and inaterials are being developed, primarily to increase the reactor's breeding capability.

EBR-II and its associated Hot Fuel Examination Facility are the primary facilities used in this area. When the FFTF is completed, it also will have a major role in carrying out experiments for developing fuels and materials. The FFTF will be the largest, highest performance fuel test facility in the world.

One additicnal facility (projected to cost $\$ 50$ million) is planned for this area It will be used to examine fuels and materials irrauiated in FFTF and CRBR.

Uncertainty concerning the

continued availability of

gualified commercial fuel fabricators

In 1967, when LMFBR became AEC's highest priority reactor cevelopment program, AEC determined that a commercia: LMFBR fucl fabrication capability within this country did not exist. Since it was essential to develop such capability, AEC undertook a multiphased program to develop an industrial capability to provide enough fuel to maintain the proaram.

As part of this iffort, AEC awarded fixed-price contracts in 1972 to two companies to fabricate fuel for the first two FFTF reactor cores. These companies were already involved in nuclear fuel fabrication work for light-water reactors and had some experience with fabricating mixedcxide fuel similar to that required for the LMFBR program. Based on current projections, both fabricators will complete production of the first two cores between June and August 1975. According to ERDA, the only other market for mixedoxide fuel in the next several years will be the CRBR project. Fuel for CRBR will not have to be ordered until late 1978 to meet its schedule.

When the contract commitments for the first two FFTF cores are met, these fabricators will have no follow-on mixed-oxide fuel fabrication work and, according to ERDA, their current production facilities will probabiy be shut down. Whether these facilities could or would become operational again is uncertain. Thus there is a strong possibility that the capability (both facilities and personnel)

$l_{A}$ mixed uranium and plutonium fuel. 
of one or both fabricators will be lost to the LMFBR proaram. If the production capacity of these plants is lost and the plants are not available for further develonment, there is no assurance that the identified near-term fuel needs of both the FFTF and CRBR can be met.

Representatives of each contractor have indicated that if they could not maintain continued operations after their present commitments are met, they would have to close down their plants and would probably not reenter the field. They attributed this to the Eact that if they shut down their present facilities they would be reguired to invest a substantial amount to capital to reenter the market. They would have to either extensively modify their existing facilities or build new plants to meet changing requlotory requirements and future technology changes.

One of the contractors already has indicated that, because of overall corporate interests, the company inay decide not to participate beyo id their current contractual requirements and may not reenter the mixed-oxide fuel fabrication market.

To maintain a capability in private incustry to fabricate LMFBR fuel, a plan has beer approves whoreby ERDA will order two additional FFTF cores for future use. Only one of the two contractors is to be selected to produce the two additional FFTF cores. To select the contractor, ERDA plans to solicit bids by mid-calendar year 1975. The selected contractor would probably be asked to produce the CF3R project fuel when it is needed. ERDA antiripates that this approach will allow one contractor to continue operations until about mid-1978. If both contractors were selected to fabricate the additional FFTF fuel, ERDA estimates that there would only be enough work to carry both of them through the latter part of 1976. Thus, the possibility would stili exist that both would be forced to shut down operations and the commercial production capability of their plants would be lost.

In following this one-supplier approach, ERDA is relying on the break in operations between completion of FFTF work and beginning of CRBR work to be short enough for the supplier to continue in the business. ERDA estimates this break to be about 6 to 12 months. According to an ERDA official, this break may be reduced by stretching out the FFTF fabrication work and/or beginning work on the CRBR fuel earlier than presently scheduled. However, the length of this break is directly related to the CRBR project meeting its scheduled 
July 1982 initial criticality ${ }^{l}$ date. Since 1972, the initial criticality date of the CRBR project has been delayed for 3 years; from 1979 to 1282 .

The course of action ERDA plans to take is directed at total support of one commercial mixed-oxide fuel fabricator for producing ill of the near-term LMFBR fuel pins needed in the program. There are inherent problems with a situation where in there is a total dependence upon one supplier. This could adversely effect such things as the future prices of needed fuel, incentive of one supplier to efficiently and effectively produce LMFBR fuel pins, ard continued supply of tuel for LMFBR program needs.

In November 1974, AEC's Office of Planning and Analysis commented that this approach to support a sole commercial scurce was a departure from AEC's policy of developing competitive, free enterprise, commercial industries but that it may be justified because of the small expected near-term market for LMFBR fuel. However, this office concluded that the basis for proceeding with this approach should be reexamined if there is significant CRBR project slippage.

\section{FUEELRECYCLE}

The objective of the fuel recycle program area is to develop technology in areas of reprocessing, refabricating, and shipping spent LMFBR fuels to permit an economically competitive LMFBR to attain a doubling tine ${ }^{2}$ of less than 10 years. The fuel recycle area is currently centered in the laboracory and, according to ERDA, it is probably the least technologically advanced area at this time.

The commercial success of the breeder depends on an efficient fuel cycle wherrby fuel burned in the reactor can be reprocessed to recover the newly bred material (plutonium) as well as the remains of the spent material. This requires shipping the spent usable fuel, reprocessing it to recover any reusable material, and refabricating the recovered material into new LMEBR fuel. The efficiency of these processes will

The state of a nuclear reactor when it is sustaining a chain reaction.

The time required for a breeder reactor to produce as much fissionable material as the amount usually contained in its core plus the amount tied up in its fuel cycle (fabrication, reprocessing, etc.). ERDA expects that later, with the perfection of advanced fuels, the doubling time for plutonium production in the breeders $c$ an be made to exceed the doubling time for electrical energy demand. 
have a strong effect on fuel doubling time and hence economics of LMFBR. According to ERDA, LMFER will not be viable without an efficient fuel cycle.

The ability to recycle plutonium for use in LMFBRs is ersential to the LMFBR concept. The Nuclear Regulatory Commission is presently considering the question of allowing the recycling of plutonium in light-water reactors. In considering this question, the commission is studying the issues surrounding the safety, environmental, and safequard impacts of using plutonium. In August 1974, the AEC requlatory organization issued a draft on "Generic. Environmental Statement on the Use of Recycled Pllitonium in Mixed oxide Fuel in Light water-Cooled Reactors." A Commission official told us the Commission expects to reach a decision on the acceptability of recycling plutonium in light-water reactors in late 1977 or early 1978. This official said that a Commission decision, which does not approve plutonium recyclina for light-water reactors for health, safety, or safeguard reasons. could have an adverse effect on the acceptability of recycling plutonium for the LMFisR since the health, safety, and safeguard impacts of using plutonium are similar for both.

The long-term goal for fuel fabrication is the startup of large commercial fuel fabrication facilities in 1988 or 1989. For fuel reprocessing, the goals are to commit funds for the first commercial reprocessing plant in 1987 and to stait full-scale commercial fuel reprocessing by 1997 .

To advance the fuel cycle to the potential of rapid reprocessing of fast reactor fuels, two facilities are planned: a High Performance Fuel Laboratory and an LMSBR Fuels Rsprocessing Hnt Pilot Plant. The High Performance Fuel. Laboratory is projected to cost $\$ 54 \mathrm{mill}$ ion to build and is expected to become operational in late 1981 or early 1982. It will be used to demonstrate fabrication of LMFBR fuel using plutionium from light water reactors and will provide the technological base for designing and operating economic high production licenseable commercial plants.

The LMFBR Fuels Reprocessing Hot Pilot Plant, consistina of a storing and receiving facility and an experimental reprocessing plant, will Aemonstrate the technology of receiving, handiling, storing, and reprocessing spent LMFBR fuel (initially FFTF and CRBR fuels) with full-scale equipment. The storing and receiving facility is presently estimated to cost $\$ 100 \mathrm{milli}$ on and is expected to begin operating in mid1981. The experimental reprocessing facility is estimated to cost $\$ 200 \mathrm{mili} i \mathrm{on}$ and is expected to beg in operating in $\mathrm{f}$ is cal year 1985. 
The objective of the LMFBR safety proaram is to investigate and develop the technology necessary to resolve safety concerns related to the LMFBR concept. The program aims to develop sufficient technology to get a generally accepted view that LMFBRs do not represent an undue hazard to the hedlth and safety of the public. The program is intended to demonstrate that

--accidents leading to major core disruption will not happen;

--even if accidents do happen, the system can be designed to preclude serious damage; and

--even if the system were seriously damaged by an accident, the consequences will not harm the public.

According to ERDA, the safety area has received considerable emphasis, many basic safety questions have been answered, and a large amount of technology is available. One major question yet to be answered is that of recriticality occurring if a core disruptive accident happens. Before large commercial plants are built, the probability of a core disruptive accident happening must be shown to be sufficiently low so that it becomes unimportant or it must be demonstrated that such an accident does not have serious public consequences. As the LMFBR plants become larger so could the potential conseguences of a core disruptive accident. A point could be reached where design options to maintain safety margins are not economically feasible; therefore, failure to satisfactorily resolve the core disruptive accident guestion might limit the size of commercial plants.

ERDA anticipates that safety work will be completed in the $1990 \mathrm{~s}$ but that funding will continue to be provided for safety research and development for as long as LMFBRs are being built.

Several inajor facilities, including the Transient Reactor Test Facility in Idaho, are now used in the safety program. This facility is used to test the behavior of fuel under changing temperature and power conditions. One other

IThe reassembly of the molten fuel during an accident into a mass capable of releasing potentially large amounts of energy. Soine experts hypothesize that an accident involving recriticality cruld cause an energy release sufficient enough to leak irom the reactor containment building and release radioactive material to the environment. 
major facility is planned--a Safety Research Experiment Facility.

The Safety Research Experiment Facility is oresentlv estimated to cost $\$ 230 \mathrm{mill}$ ion and is expected to beain operations in the rilid-1980s. This facilitv will provide a fast-flux zone for testina up to seven full-scale LMFBR fuel assemblies to and through total loss of fuel element integrity. It will enable data to be developed to address outstanding safety issues--such as the question of recriticality--and will provide input into the desiqn evaluation process of cominercial LMFBR designs and data to respond to concerns of licensing bodies and citizen groups. It will also provide the capability of conductind orototypic tests under conditions of hypothesized LMFBR accidents.

Accordina to ERDA, this Dlanned facility is not needed to provide safety data before the scheduled July 1982 operation of the $\mathrm{Clinch}$ River Breeder Reactor demionstration plant because conservative desian features and marcins are included in the present CRBR desian. However, it is needed to provide data for the design of laraer plants as these same conservatisms and margins impose substantial economic venalties on the cost of energy to be obtained.

\section{COMPONENT EFYELOPMENT}

The objective of this area is to insure the availability of plant components and systems with demonstrated capability of meeting the exacting performance requirements of commercial LMFBRs, including reliability, safety, economy, operability, and ease of maintenance. This area is in transition from focusing on near-term needs (FFTF and CRBR) to focusina on component sizes of interest to commercial plants. Accordina to ERDA, progress to date in developing components, particularly those to be used in FFTF, has not been satisfactory.

According to ERDA, many component featlires are beina developed which are applicable to large plants, but it is recessary to proof test the full-size components to provide assurance that they will operate reliably under conditions typical of power plant services. Facilities currently available within the program are inadequate for testina the larqesize components. Consequently, a Plant Component Test Facility, which will serve as a test bed for commercial-size components, has been added to the LMFBR program plan. This facility is estimated to cost about $\$ 200$ million and is planned for operation in the early 1980s. ERDA expects that testing components for the near commercial olant will be completed by 1984 . 
In addition to the Plant Component Test Facility, ERDA plans to construct a Radiation and Repair Enqineerina Facility--estimated to cost $\$ 36 \mathrm{million--for}$ maintaining and repairing large, radioactive sodium-contaminated components.

Present emphasis in the component develooment area is on the development of components for CRBR. Fabrication of prototype components is scheduled to begin in 1975 with testing to follow. The critical components--the pump and steam generator--are scheduled for testing in 1977. According to ERDA, this will be early enough to allow rework, if necessary, based on the test results, before installing these components in CRBR.

\section{PLANT EXPERIENCE}

The objective of this area is to demonstrate the licenseability, operability, flexibility, safety, reliability, availability, inspectability, maintainability, environmental acceptability, and economy of LMFBR. The plant experience area of the LMFBR program is where technoloay developments are integrated into an operating reactor to demonstrate the feasibility of the total concept. According to ERDA, olant experience is acquired by designing, constructina, and operating a succession of olants--progressing in size throuah reasonable extrapolations of technology--until the commercial piant is reached. Limited experience has been achieved from operating several U.S. reactors, and more is expected from FFTE.

ERDA believes that successfully comcleting CRBR and the near commercial plant (see $p .8$ ), together with the experience gained from foreign LMFBR programs, should provide adequate experience for the U.S. breeder industry. CRBR will serve to demonstrate LMFBR reliability, safety, licenseability, and environmental acceptability, focusing industry and utility efforts on establishing the commercial viability of the concept.

According to ERDA, the near commercial plant, referred to as the Near Commercial Breeder Reactor (NCER), is to provide the large-scale plant experience necessary to initiate full industrial participation for commercializing the LMFBR. The experience of ERDA and private industry with this facility should determine how much work on the LMFBR concept is necessary before it is fully accepted by the nuclear industry and integrated into utilities' power production systems. NCBR is not well defined yet except that it is expected to be a large, commercial-size LMFBR (in the 1,000 to 1,500 MWe power range) which uses large, commercial-size components. This size would generate about four times as much power as CRBR. 
ERDA plans to fund work on designs of larqe plants which must be begun before designing and constructing iNCBR. These designs--known as LMFBR Target Plant Designs--are also expected to provide essential technical inrut to the full-size component development and testing oroqram as well as to the rest of the LMFBR base technology effort.

Work on the LMFBR Target Plant Designs is expected to beg in in mid-1975. Two or more reactor manufacturers are to be selected to develop enginetring designs of commercial LMFBRs which these reactor manufacturers might propose to market. This effort is expected to last about 3 years.

The Electric Power Research Institute ${ }^{l}$ has expressed an interest in participating with ERDA in the conduct of the Target Plant Designs and has indicated a willingness to share substantially in the costs. Negotiations are presently underway to determine the extent of the Institute's involvement and cost sharing arrangements.

AEC previously funded a similar design effort which ended in 1968. New designs are now needed, according to ERDA, because substantial changes in the program and considerable advances in the technology have occurred since 1963.

Uncertainties associated with_NCBR

ERDA envisions that NCBR will be a cooperative project between the Government and the nuclear utility industry and that the Government's assistance to the project will be substantially less than that required for CRBR (presently estimated at about $\$ i .5$ billion). The cost estimate, schedule, and degree of industry participation has not yet been determined. However, AEC's preliminary estimate of NCBR's cost was $\$ 2.0$ billion. ERDA expects that the nuclear utility industry will commit funds to the project beginning in 1977 and that the project will be completed in 1986.

Although they are not certain, ERDA officials told us that more than one NCBR may be needed and that the Gover:ment might need to provide funds to supplement industry investment for any additional NCBRs. ERDA officials told us that in the past under the Power Demonstratrion Plant Pro-

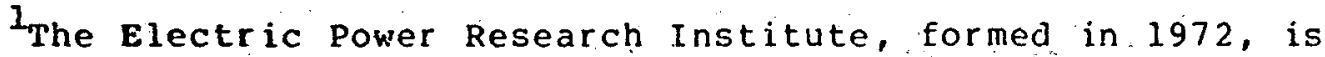
supported by all segments of the electric utility industry to fund electric research and development projects. Its goal is to develop a broad, coordinated, advanced technological program for improved electric power production, transmission, distribution, and utilization in an environmentally acceptable manner. 
gram, AEC's approach was to provide funds for follow-on plants until their power costs l become competitive with then available power sources. If ERDA chooses this same approach, Government funds would be added to private industry investment for iNCBRs until such time as the costs per installed kilowatt of breeder electrical generating capacity are about the same as for liaht-water reactors (or other power sources) of the same generatina capacity. ERDA estimates the capital costs for the initial NCBR--not including research and development costs--could be as high as $\$ 1,000$ per installed kilowatt of capacity. The same costs for a light-water reactor are now about $\$ 500$ per installed kilowatt.

ERDA officials said that they have no sound basis for predicting the extent of cost sharing on the initial NCBR. The estimate of what the LMFBR program will cost throuah 2020 specifies that ERDA's contribution for NCBR will be $\$ 300$ million. As pointed out on page 11, there is a large amount of uncertainty related to the $\$ 300 \mathrm{mill}$ ion in planned assistance.

\section{FACILITIES USED IN THE LMFBR PROGRAM}

In a July 1974 report to the office of Management and Budget, AEC listed 96 facilities in the LMFBR progiom. AEC officials told us, however, that this list included both major and non-major facilities.

We identified 22 of these facilities, which AEC built or ERDA is presently building, as being major construction projects. ERDA plans to build eight more facilities for the program. These present and planned facilities are generally multipurpose facilities which have a relatively long useful 1 ife and large acquisition cost and are not limited to a narrow technical objective or task. The approximate total construction cost of these present and planned facilities, which is included in the LMFBR program cost estimate, is about $\$ 3$ billion. Several of these facilities --such as EBR-II, FFTE, and CRBR--have been previously mentioned and discussed in this report.

Numerous other facilities, which ERDA does not consider major facilities, are used in the program. These include experimental support apparatus which have a relatively short

\footnotetext{
These costs include both capital power costs and fuel cycle costs. LMFBR fuel cycle costs are expected to be lower than light-water reactor fuel cycle costs. Consequently, LMFBR capital investment costs can be higher than those for lightwater reactors and the total investment for the two types of plants could be competitive.
} 
life and à single or limited purpose.

Appendix IV presents a listing of major facilities bv LMFBR program area. Appendix $V$ presents a detailed listina, including cost and schedule information, of those present and planned major LMFBR support facilities.

Information on certain key LipBR facilities

EFTE

The FF'T is to be a key testing facility for fuels and materials used in the LMFBR proaram. In July 1967, the Congress authorized construction of FFTF which, at that time, was estimated to cost $\$ 87.5 \mathrm{mill}$ ion and scheduled to begin full-Dower operation in early 1974. Since conaressional authorization, FFTF has experienced substantial cost growth and schedule slippage. The FFTF cost and schedule estimate has been revised several times. The latest official cost estimate (Februafy 1974 ) for the construction of the facility is $\$ 420$ million. At this same time, the construction completion schedule had slipped to November 1977; no estimate was made for the full-power operation milestone.

The FFTF contractor is presently forecasting that an additional $\$ 92 \mathrm{mill}$ ion will be needed to construct the FFTF. Also, as of December 31, 1974, the latest field estimate for construction completion was Auqust 1978, with full-power operation expected to occur 18 months later.

\section{Sodium Pump Test Facility}

The construction of the sodium fump Test Facility was authorized in the fiscal year 1966 budget. The estimate presented to trie Conqress for approval at that time was $\$ 6.8$ million. In 1969 a review of the project by a private architect-engineering firm revealed that the project, with its then current scope, would cost $\$ 25.2 \mathrm{million}$.

To reduce estimated costs, the project scope was then revised to test sodium pumps having a capacity of about onethird the size of those initially anticipated to be tested. The reduced project scope resulted in a cost estimate of $\$ 12.5$ million for the facility. This estimate was presented

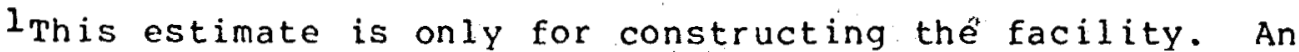
additional $\$ 505 \mathrm{mill}$ ion was estimated for equipment, research and development, and other sunporting costs for a to ial program cost of $\$ 9.25 \mathrm{mill}$ ion. A complete estimate for these costs was not prepared when the initial $\$ 87.5$ million estimate was prepared. 
to and approved by the Congress as part of AEC's fiscal year 1972 budget request. In fiscal year 1974, this $\$ 12.5$ ritillion estimate was again revised up to $\$ 17.5 \mathrm{milli}$ ion. At that time, AEC stated that the reduced capability of the facility would not adversely affect the capability to test oumps up to the sizes needed for use in the forseeable future of the LMFBR program.

ERDA is presently planning modifications to this facility so it can test CRBR-size pumps, which are larger than the pumps for which the facility is presently designed. These modifications are prescntly estimated to cost $\$ 40 \mathrm{million}$, increasing the project's total cost to $\$ 57.5$ million.

\section{CRㅗR}

CRBR will be the Nation's first demonstration LMFBR power plant. In september 1972, during hearings before the Joint Committee on Atomic Energy. AEC nresented its estimate of what the demonstration plant would cost--\$Eş million; the Federal Government would provide $\$ 422 \mathrm{mill}$ ion through AEC and industry would provide the balance. The project was scheduled to achieve initial operation in 1979. Since then, the CRBR has incurred considerable schedule delay and cost growth. In september 1974, following an extensive effort to establish a reference desian, schedule, and cost estimate, AEC estimated that the project will cost $\$ 1.736$ billion and would not be initially operable until July 1982--an increase of more than $\$ 1$ billion and a delay of about 3 years. Because of an open-ended commitment, tho federal Government's contribution to CRBR would increase to $\$ 1.468$ billion. As a result, ERDA is planning to seek additional authorization for CRBR in early 1975.

As of March 1975, ERDA's Division of Reactor Research and Development was forecasting that CRBR would cost $\$ 1.771$ billion and that the funding problems that the project is incurring will cause the project schedule to slip 3 months. 
ERDA's Division of Reactor Research and Development (RRD) is directly responsible for developing and directina the LMFBR program and for providing the needed technology to develop and support a commercially $v$ iable breeder reactor economy. It is also responsible for supporting other nuclear electric power concepts on an as-needed basis to meet future U.S. power demands. RRD recently made a number of changes designed to improve management of the LMFBR program.

ERDA has operations offices throughout the country to, among other things, administer tre contractors' LMFBR activities within defined geographic areas.

\section{RRD ORGANIZATION}

RRD is organized on a project basis, that is, individual assistant directors are directly responsible for specific areas and projects within the division. Under this organization, there are 14 assistant directors, 8 of whom are involved directly in the LMFBR program. These are assistant directors for programs, reactor safety, engineering and technology, component engineering and development, LMFBR support facilities, commercial plant program manaqement, CRBR program management, and FFTF program management. The other RRD assistant directors are assigned either to other reactor development programs (e.g., gas-cooled reactor projects) or to program support organizations (e.g.. administration). (See appendix VI for an organization chart of RRD.)

RRD has been organized on a project basis since November 1973. Before then the division was operating on a tunctional basis with various assistant directors responsible for specific technological areas in the overall program. According to $A E C$, RRD was reorganized tc give the individual assistant directors more direct authority and to establish defined areas of responsibility for major segments of the LMFBR development program.

\section{MANAGEMENT CONTROL SYSTEM WITHIN RRD}

RRD is in the process of implementing a new system for administering, managing, and controlling its various programs, of which the LMFBR is the most important. This manaqement control system is intended to provide increased $v i s i b i l i t y$ and better control over RRD programs. 
Several factors provided the imoetus, for RRD's new management syctem, including two GA.O reports to AEC regardina LMFBR program planning, delays in reachind agreement on brogrammatic and technical marters affecting the program, and a need to promptly keep top manadement better informed of problem areas. These factors focused top level attention on the management performance of RRD.

In June 1974, RRD contracted with a private consuiting firm to identify ways of improving its management control system. Weaknesses of the former management system were identified and were used to develon objectives for imorovina the management system. The objectiven were to:

--Insure proper visibility of RRD programs by proper long and short term olanining.

--Provide the a i ity to forecast technical and financial problems. According to RRD, this should reduce the time the RRD staff used in "fire-fighting" (i.e., responding to problems that arise during the course of dav-to-day operations).

--Establish closer control over the costs and schedules of RRD programs and supporting projecis combined with a method of tracking the activities involved in the various aspects of them.

--Drovide adequate and timely reports to upper manaqement.

--Permit more attention by the assistant directors to the management of their programs.

--Reduce and simplify all RRD reporting requirements.

The integration and implementation of the management control system into the management structure of RRD will be a gradual process and is expected to take 1 or 2 years.

The management control system consists of five management functions: planning, directing, information management, reporting, and reviewing. The planning and directing functions have progressed well toward full integration and implementation into the system. The information management, re-

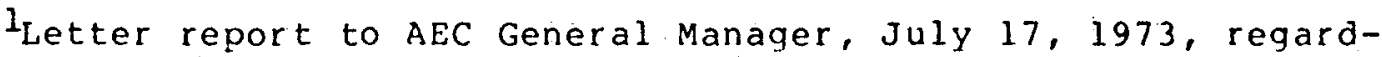
ing the management of the LMFBR program and letter report to the Chairman, AEC, June 29, 1973, regarding the need for better reporting requirements on AEC's construction projects $(B-164105)$. 
porting, and reviewing functions are in the early stages of development. Each of these functions are briefly discussed below.

\section{Planning}

This function consists of two primary elements--a Division Plan and supporting Assistant Director Plans. The $D^{i} i-$ sion Plan will be RRD's basic management nlanning document which identifies with its objectives and the strateay for achieving the objectives. It should provide an overall picture of RRD programs and activities, the responsibilities for carrying out these programs, and the objectives they support--plus the resources and constraints within which they are to be accomplished. The olan is to be the focal point for control and visibility of all RRD activities at the director's level and is to serve as the base for qauaing the progress of programs and the performance of various levels of management within RRD. Before initiating this Division Plan concept, top RRD management had no formal overall planning document, excepe budget oriented type information.

The Assistant Director Plans will be the basic management planning document for each assistant director. Each assistant director is to prepare these plans based on the Division plan. The plans must define the objectives, activities, schedules, budgets, and milestones for the assistant director's area of responsibility. These plans, which must be approved by the Director, RRD, should provide lonq-range visibility and nea,-term control of the activities of each assistant director. They are to be the basis for tracking and comparing technical and financial status. The plans will be issued annually and updated at least once during the year to reflect proqress and charges in direction.

\section{Directing}

This function is designed to insure that the established plans are implemented properly and consistently throughout and among RRD. The director's primary means of directing the efforts within RRD will be through policy and procedural guides and various program direction letters in which the director assigns objectives to the assistant directors. The assistant directors are responsible for issuing to the field various program direction letters to authorize ongoing work. The division director formerly did this.

\section{Information management}

The improved information management system, when fully developed, should direct relevant programmatic and project data to the appropriate offices and individuals within RRD. 
Because of the large amounts of such information generated within the program, such a system, if properly implemented, should provide program management with a much needed mechanism for filtering out unnecessary information which can hinder management efficiency.

\section{Reporting}

The reporting elements of the manaqement control system wil? specify what reports are to be produced, the information that is to be included in the reports, and the format that is to be followed. This reporting system is intended to provide consistent, meaninaful, and timely information to RRD manaaement.

The information management and reporting functions are to work together to insure that the RRD management is pro$v$ ided with the information they need to meet their respective programmatic responsibilities and are not inundated with unnecessary data and reports.

Reviewing

This function's objective is to provide RRD management with feedback and assessment on critical proqrams and projects within RRD (e.g., FFTF, CRBR). There are two key review ele-ments, the program control center and formal project reviews, which formerly did not exist. A prooram control center is to be established and will display updated project information and the status of all RRD programs. Formal project review meetings, at which the assistant directors will present the status of their programs to RRD's director, are to be held on reguiarly scheduled basis. The main point of these meetings is to be a thorough discussion of problems, including cause, impact, remedial action, and prognosis. Several project reviews have al read" been held.

\section{CONCLUSION}

As previously pointed out, ERDA has identified weaknesses in its overall management control system and it has developed a number of objectives aimed at imoroving the system. These goals, if achieved, should reasonably insure that ERDA management will have greater visibility over LMFBR programs a:a that it will be in a position to better focus managemer: attention and direction over those areas of the program having problems.

ERDA expects that integrating and implementing the new management control system will ce a gradual process and that it will take 1 to 2 years to fully implement. Because of the importance of this program in helping to solve the Na- 
tion's energy problems and because of the large amounts of funds estimated to be spent on LMFBR development, ERDA should strive to implement the system as soon as nossible.

The actions ERDA has taken and is taking to improve its management control system are steps in the right direction.

CRBR PROJECT ORGANIZATION

In July 1973, after extensive negotiations and hearinas before the Joint Committee on Atomic Enerqy, AEC entered into a contracr with the Tenriessee valley Authoritv, Commonwealth Edison Company, and Project Manamement Corporation to huild the Nation's first LMFBR d ionstration plant. This nroject is being funded jointly by the Government and private industry, particularly the Breeder Reactor Corporation, which administers the financial contributions from the Nation's electric utilities. Project Manaament corporation, a not-forprofit corporation formed in 1972, is providing overall management and coordination for designing, constructirig, and operatina the plant and has the lead role for the non-nualear portions of the plant. The Tennessee Valley Authority is providing the $\mathrm{Clinch}$ River site for the project. It will own and operate the plant and will purchase the power produced by the plant. Commonwealth Edison is supplyind enqineering management and purchasing services for the oroject. ERDA has the lead roie responsibility for the nuclear portion of the project and, through the CRBR project office, provides Project Management Corporation contract administration services on an as-needed basis.

A three-man steering committee with representatives from ERDA, the Tennessee Valley Authority, and Commonwealth Edison directs the Project Management Corporation role (throuah the Project Management Corporation's General Manager). This group implements project policy and agreements. ERDA's representative is the director of RRD. (see appendix VII for a chart showing the current CRBR management or aanization.)

This organizational arrangement for the project is complex and Dotentially cumbersome. This has been recoanized hy the project participants involved. Officials involved in the project told us that no major oroblems have thus far resultad from this complex organization structure. However, ERDA of iciais told us that the reason no problems have resulted is because of the compatibility of the personalities of the two individuals most directly involved in manaqina the project--the Project Management Corporation's ar eral manager and the RRD assistant director for the demonstration plant project. These two individuals, according to ERDA officials, have been able to work out any differences and have been able to make the project go. 
As evidence of this relationship and its effects on the management of the project, we noted a letter had been submitted by the Project Management Corporation's qeneral manager to RRD management reflecting problems project Management corporation management had administering its responsibilities. RRD management officials disreqarded the letter and said that the individuals involved will work out the problem and prevent any conflicts.

In our view, the organizational arrangement for the CRBR, which depends heavily upon the personalities of the individuals involved, may hinder the effective management of the design and construction of CRBR and, consequently, represents a potential risk to the project. Unless the organizational relationships and manaqement processes are streamlined, cost overruns and schedule delays might follow. An ERDA review group reached similar conclusions. Now, when the Government is expected to conmit an additional $\$ 1$ billion to the oroject, may be an appropriate time to seek a change in the present contractual arrangement to strengthen and streamline Government control over the project.

On March 10, 1975, ERDA submitted to the Joint Committee on Atomic Energy for its approval proposed leaislation and underlying documents that would provide for a new management structure for the project. Essentially, management control of the project would be transferred from the Project Management Corporation to ERDA, commensurate with the Government's investment in the project. This new management structure is intended to strengthen and streaml ine Government control over the project.

In a April 4, 1975, report to the Joint Committee on Atomic Energy entitled "Comments on Energy Resear ch and Development. Administration's Proposed Arrangement for the $\mathrm{Clinch}$ River Breeder Reactor Demonstration Plant Project" (RED-75-361), we pointed out that the various documents ERDA submitted to the Joint Committee did not clearly delineate the manner in which the project would be managed, but rather contained ambiguous and seemingly inconsistent language regarding responsibilities and authorization for management. In addition, we stated that such inconsistencies suggested that ERDA would not be able to exercise the usual management prerogatives in the areas ct design and other changes and that it might be subject to restraints in other management areas. 
CHAP'TER 4

FUNDING FOR ENERGY RESEARCH AND DEVELOPMENT

Energy Research and Development (R\&D) funding has grown markedly since 1971 and is now one of the fastest growing areas of the Federal budget. Energy $R \& D$ funaing, as a percentage of total Federal R\&D funding, has $r$ isen from 2.3 percent in 1969 to an estimated 8.1 percent in 1976 , as shown in the table below.

$\begin{array}{lccc}\begin{array}{c}\text { Total } \\ \text { Federal } \\ \text { year }\end{array} & \begin{array}{c}\text { Total } \\ \text { Federal energy }\end{array} & \begin{array}{c}\text { Percentage } \\ \text { energy to }\end{array} \\ & & \text { R\&D } & \\ & \$ 16.3 & \$ .38 & 2.3 \\ & 15.9 & .38 & 2.4 \\ & 16.2 & .42 & 2.6 \\ & 17.2 & .54 & 3.1 \\ & 17.6 & .67 & 3.8 \\ \text { (estimated) } & 18.3 & 1.02 & 5.5 \\ \text { (estimated) } & 19.8 & 1.67 & 8.4 \\ & 22.5 & 1.84 & 8.1\end{array}$

AEC, Department of tha Interior, the National Science Foundation, and the Environmental Protection Agency had carried on tie bulk of the Federal energy R\&D effort. With the establishment of ERDA in January 1975, most of the effort will be centered in that agency.

The ciffice of Management and Budget has maintained data on total Federal energy $R \& D$ funding since fisca. year 1973. Before that time, the National science Foundation was the only central source of information on Federal energy R\&D.

PROPOSED FISCAL YEAR 1976

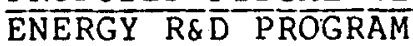

The proposed fiscal year 1976 Federal budget estimate includes about $\$ 1,837 \mathrm{milli}$ ion for energy $R \& D$. These funds are to support a broadly based effort on technologies for energy supply, environmental control, and conservation. The following table shows the proposed. Federal energy R\&D program for fiscal year 1976 along with historical and planned funding for energy $R \& D$ program areas. 


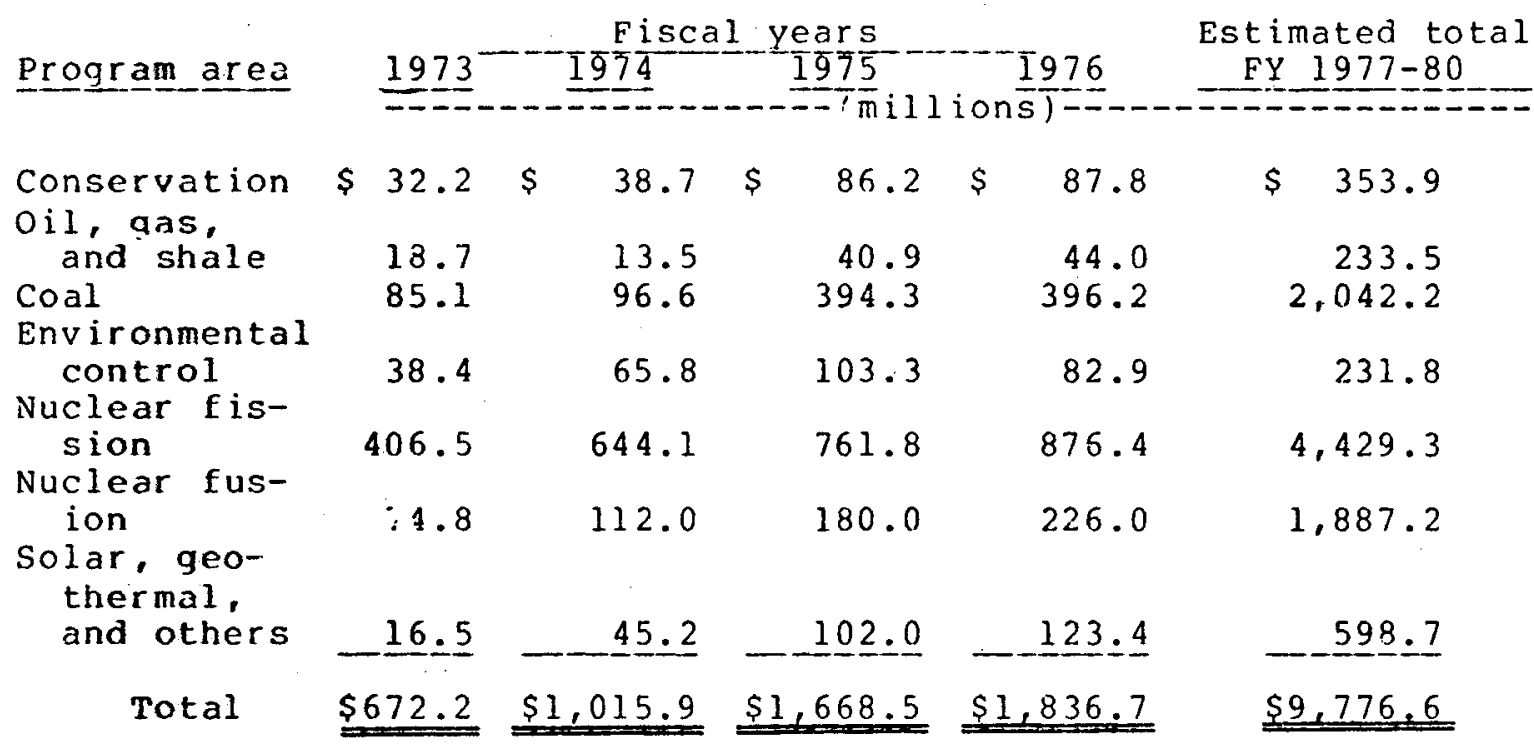

The energy R\&D program is desianed to accelerate the development of technologies needed to achieve and maintain a capability to more fully utilize domestic energy resources within acceptable environmental and economic costs.

ERDA's energy R\&D accounts for a major portion of the total Federal energy $R \& D$ budget. The following table shows this relationship since fiscal year 1969 .

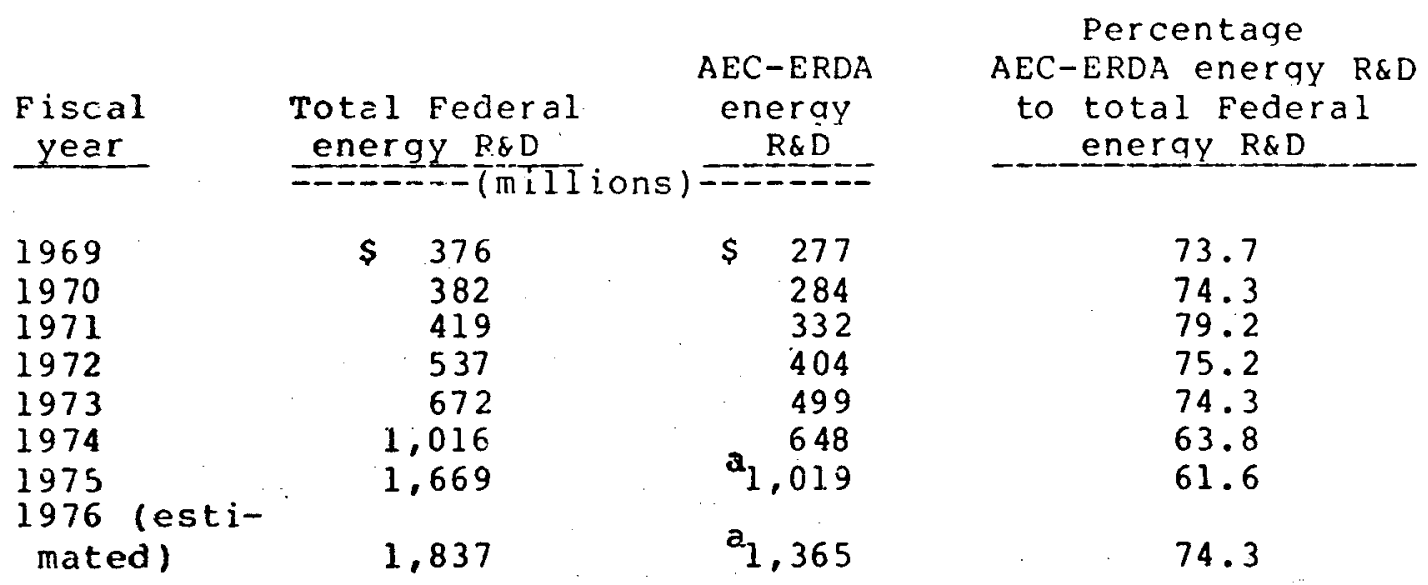

These figures include energy $R \& D$ programs transferred from other agencies to ERDA as of January 19, 1975.

As indicated above, AEC funding as a percentage of the total Federal energy R\&D budget had decreased from 73.7 percent in 1969 to 63.8 percent in 1974. With the establishment of ERDA, the percentage of the ERDA energy R\&D budget 
increased substantially to an estimated 74.3 percent in fiscal year 1976 .

\section{LMFBR PROGRAM FUNDING}

The largest nuclear program is ERDA's civilian fission raactor program. Most of this program is devoted to developing LMFBR. The LMFBR program is a major portion of the Nation's effort to achieve energy self-sufficiency in the next decade and to maintain it into the next century. Althouah the amount of LMFBR expenditures has been increasing, the percentage of these expenditures to total Federal energv $R \& D$ has been decreasing since fiscal year. 1973, as shown in the following chart.

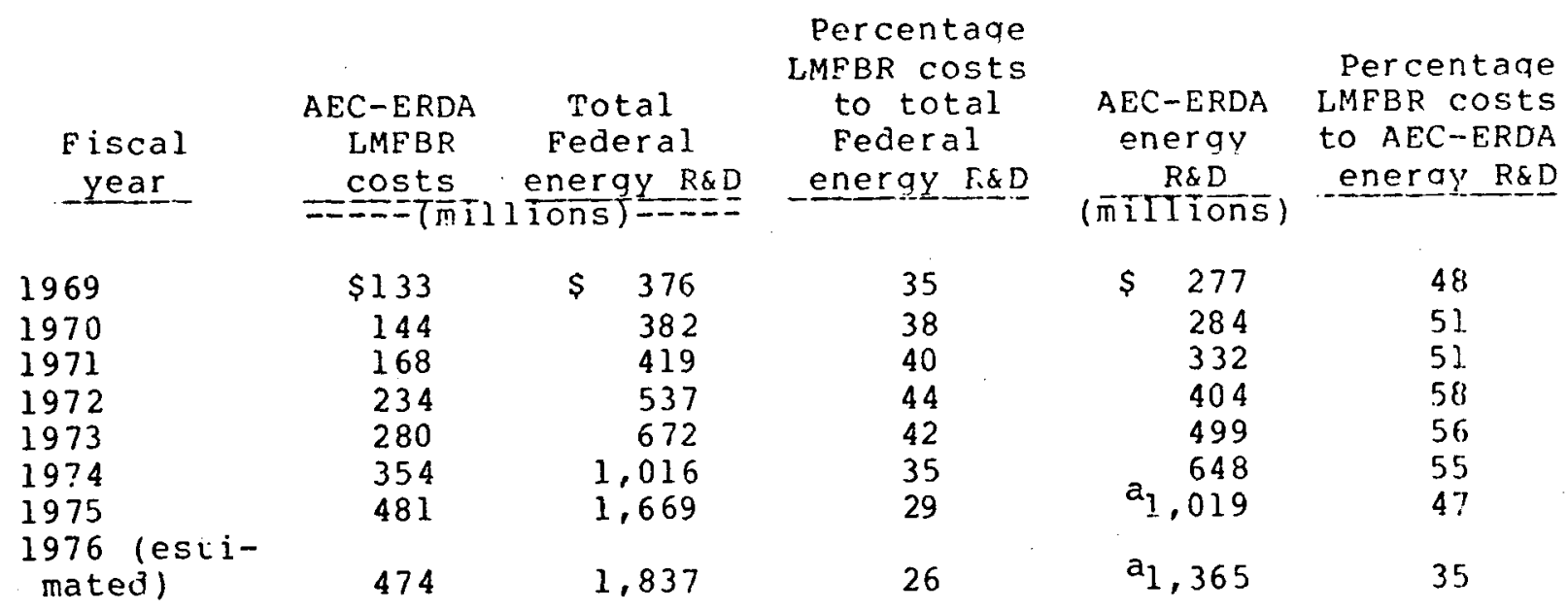

aThese figures include energy $R \& D$ programs transferred from other agencies to ERDA as of January $19,1975$.

Regulatory costs for LMFBR program activities

The AEC-Regulatory (now the Nuclear Regulatory Commission) costs for their activities relating to the licensing and surveillance of LMFBRs, as discussed on page 10, are not included in the above figures. These costs amounted to $\$ 1.1$ million in fiscal year 1973, \$1.l million in fiscal year 1974 , and are expected to be $\$ 1.5 \mathrm{mill}$ ion in $\mathrm{fiscal}$ year 1975 and $\$ 21.2 \mathrm{mill}$ ion during $\mathrm{fiscal}$ years 1976 through 1980 . 


\section{CHAPTER 5}

\section{FOREIGN LMFBR PROGPAMS}

LMFBR is a high priority national energy development program of five other major industrial nations. The United Kingdom, France, Japan, West Germany, and the Soviet Union have work underway on breeder reactors. The United Kingdom, France, and the Soviet Inion al ready have demonstrationsize breeders in operation; West Germany and Jaban have plants scheduled for operation by 1979 and 1980 , respectively. The following table, taken from AEC-ERDA documents, 1 is ts the LMFBR projects throughout the world which are operable, under construction, or planned.

\begin{tabular}{|c|c|c|c|c|}
\hline \multirow[b]{2}{*}{ lame } & \multirow[b]{2}{*}{ Country } & \multicolumn{2}{|c|}{ Power } & Initial \\
\hline & & MWt & MWe & Operation \\
\hline
\end{tabular}

Operable

\begin{tabular}{|c|c|c|c|c|}
\hline $\begin{array}{l}\text { BR-10 (note a) } \\
\text { Dounreay Fast }\end{array}$ & USSR & 10 & -- & 1959 \\
\hline Reactor & United Kingdom & 72 & 14 & 1959 \\
\hline EBR-II & United States & 62.5 & 16 & 1963 \\
\hline Rapsodie & France & 40 & -- & 1967 \\
\hline BOR- 60 & USSR & 60 & 12 & 1970 \\
\hline $\mathrm{BN}-350$ (note $\mathrm{b})$ & USSR & 1,000 & 150 & 1972 \\
\hline Phenix & France & 600 & 250 & 1973 \\
\hline $\begin{array}{l}\text { Prototype Fast } \\
\text { Reactor }\end{array}$ & United Kingdom & 600 & 250 & 1974 \\
\hline Under construct is & or planned & & & \\
\hline Joyo (note c) & Japan & 100 & -. & 1975 \\
\hline $\begin{array}{l}\mathrm{KNK}-2(\text { note } d) \\
\mathrm{BN}-600\end{array}$ & $\begin{array}{l}\text { West Germany } \\
\text { USSR }\end{array}$ & $\begin{array}{r}58 \\
1,500\end{array}$ & $\begin{array}{r}20 \\
600\end{array}$ & $\begin{array}{l}1975 \\
1977\end{array}$ \\
\hline FFTE & United States & 400 & -- & 1977 \\
\hline $\begin{array}{l}\text { SNR- } 300 \text { (note e) } \\
\text { Super Phenix } \\
\text { (note f) }\end{array}$ & $\begin{array}{l}\text { West Germany } \\
\text { Erance }\end{array}$ & $\begin{array}{r}730 \\
3,000\end{array}$ & $\begin{array}{r}300 \\
1,200\end{array}$ & $\begin{array}{l}1979 \\
1979\end{array}$ \\
\hline $\begin{array}{l}\text { Monju } \\
\text { Commercial Fast }\end{array}$ & Japan & 720 & 300 & 1980 \\
\hline $\begin{array}{l}\text { Reactor } \\
\text { RRR }\end{array}$ & United Kingdom & 3,125 & 1,320 & 1981 \\
\hline $\begin{array}{l}\text { CRBR } \\
\text { SNR-2 (note f) }\end{array}$ & $\begin{array}{l}\text { United States } \\
\text { West Germany }\end{array}$ & $\begin{array}{l}1,000 \\
5,000\end{array}$ & $\begin{array}{r}400 \\
2,000\end{array}$ & $\begin{array}{l}1982 \\
1984\end{array}$ \\
\hline
\end{tabular}

anitially started up at 5 MWt and power level increased to 10 MWt in 1973.

bual purpose: 150 MWe for electric power and 200 MWe equivalent for desalination. 
$c_{\text {To }}$ be operated to 50 MWt initially.

doperable as thermal reactor (KNK-1) until late 1974 .

eIn cooperation with Belgium and the Netherlands.

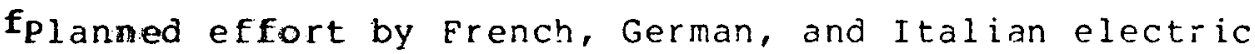
utilities.

STATUS OF THE MAJOR LMFBR PROGRAMS

We obtained information on the foreign LMFBR programs from ERDA-AEC officials and documents.

\section{France}

France has one of the more advanced foreign proqrams in reactor development and has perhaps the greatest national commitment to the LMFBR concept. The French fast reactor research program began with fundamental research on liquid metals in the early 1950s. Construction of the Rapsodie fast breeder reactor began in 1962 with operations beginning in 1967. The successful operation of the Rapsodie reactor led to the French Government's decision the next year to build Phenix, a 250 MWe LMFBR prototype. Construction of Phenix was started in late 1968 and completed in late 1973. The reactor began operations in 1973 and reached full power in March 1574. As of February 1975, Pherix was operatina smoothly and had encountered no major problems.

The French, in a combined effort with German and Italian electric utilities, are now planning for Super Phenix, a 1,200. MWe commercial fast breeder po'ner station. Construction is expected to start in March 1975, after l year of successful phenix operation. Super phenix represents a major extrapolation in existing technology. Phenix is not prototypical of Super Phenix in a number of important comporents, such as steam generators, intermediate heat exchangers, and fuel.

France is also considering entering the commercial market with a 450 vwe Phenix which would be based on the Phenix design and components. The plant would be a direct extrapolation from Phenix without any new technology risk.

\section{United Kingdom}

Studies of fast reactors in the United Kingdom started in the early 1950s. An early step in the United Kingdom LMFBR effort was their Atomic Energy Authority's 1955 decision to build the 14 MWe Dounreay Fast Reactor. The purpose of this reactor, which began operations in 1959, was to demonstrate the feasibility and safety of LMFBRs. It has also served as 
a facility to test fuels and materials.

$\triangle s$ a result of the successful operation of the Dounreay Fast Reactor, construction of the 250 MWe Prototype Fast Reactor was started in 1966. This reactor began operations in 1974 and is currently operating at low power. Full power operation is expected in early 1975. Problems encountered in constructing and commissioning this reactor resuited in about a 2-year delay in schedule.

The detailed desion of commercial fast breeders is currently underway in the United Kingdom. The construction of a commercial fast reactor of $1,300 \mathrm{MWe}$ is scheduled to beg in in 1977 with operations expected to begin in 1981 or 1982 .

\section{Japan}

The Japanese Atomic Energy Commission toqether with electric utilities and reactor manufacturers began a study of nuclear power reactors in the mid-1960s. On the basis of this study, the Japanese Government established the Power Reactor and Nuclear Fuel Development Corporation in 1967. The goal of this corporation was to bring LMFBRs into practical use as power producers by the latter part of the 1980s.

To achieve this goal, the corporation is developing a 100 MWt experimental fast breeder reactor, Joyo, and a 300 MWe prototype LMFBR, Monju. Construction of Joyo was started in 1970 and operations are expected to begin early in 1975 . Design work on Monju is presently underway with construction planned to start in 1975 or 1976 and operations expected to beg in in 1979 or 1980 . The main purpose of this project is to demonstrate the performance, reliability, and economy of LMFBR nuclear powerplants as well as to gain experience for larger commercial plants. The conceptual design for a 1,500 MWe commercial LMFBR has also been completed with corstruction presently pianned to start around 1980.

\section{West Germany}

West Germany has no iarg a national atomic energy agency. Instead, their Federal Government provides financial assistance to individual German states for nuclear energy research and development. The German fast reactor program was started in 1960 at the Karlsruhe Nuclear Research Center. Construction of a 20 MWe sodium cooled thermal reactor was started in 1966; it began operation in 1972. It is being modified for operation as a fast reactor $(K N K-2)$ and is scheduled to be placed in operation in late 1975. 
The commercial design of a 300 MWe prototype LifFBR (SNR300 ) was begun in $1966-67$ as a jointly financed project by West Germany ( 70 percent), Belgium, and the vetherlands (about 15 percent each). Luxembourg also participated. Its construction began in early 1973. The reactor is expected to start operation in 1979 .

In 1971 a West German utility company and a French utility company signed an agreement to build two commercial LMFBRs. Later, Italy joined the agreement on a one-third participation basis. The first plant (Super Phenix) is to be 1,200 MWe; construction in France is to start in 1975 . The second plant (SNR-2) is expected to be 2,000 MWe; construction is planned to start in West Germany in 1979.

\section{Union of Soviet Socialist Republics}

The USSR program is one of the more advanced foreign programs in reactor development. The USSR fast breeder research and development program is an effort of the state Committee for the Utilization of Atomic Energy and the Ministry for Power and Electrification. The proqram started in 1955 with the operation of a small plutonium-fueled reactor. A $100 \mathrm{kWt}^{\mathrm{l}}$ mercury-cooled, plutonium-fueled reactor was built in 1956. This facility was reworked inco a sodium-ccoled, plutonium-fueled reactor of 5 MWt power winch went into operation in 1959. The reactor was modified for operation at 10 MWt in $1973(\mathrm{BR}-10)$.

During the latter part of 1963, design work was initiated on a 60 MWt experimental LMFBR. Construction of this reactor, BOR-60, began in 1965 and operations began in 1970 .

The two major Soviet projects are the $B N-350$ and the $B N-600$. Construction of the $B N-350$ fast breeder reactor began in early i964. This dual purpose (power and water desalting) 1,000 MWt LMFBR provides the equivalen's of 350 MWe in steam. The reactor began operations at the end of 1972 and was placed in commercial oparation in July 1973.

The USSP. is building the world's largest LMFBR--the BN600. Construction of this 600 MWe reactor started in late 1968 and is expected to begin operations during 1977 . It has been reported that the Soviets are designing an LMFBR in the $1,000-1,500$ MWe power range.

\footnotetext{
${ }_{A}$ kiluwatt thermal; one-thousandth of a megawatt thermal. see footnote 1 on page 7 .
} 
COMPARISON OE U.S. PROGRAM WITH $\bar{E} \overline{\mathrm{R}} \overline{\mathrm{E}} \overline{\mathrm{I}} \overline{\mathrm{G}} \overline{\mathrm{N}} \mathrm{P} \overline{\mathrm{RO}} \overline{\mathrm{G}} \overline{\mathrm{R}} \overline{\mathrm{M}} \overline{\mathrm{S}}$

The U.S. approach to LMFBR's development has been to accumulate the required technological base for designing, constructing, and operating LMFBRs in the orivate sector. The U.S. program has emphasized an understanding of the full range of technology problems and their resolution before initiating the powerplant hardware phase. The U.S. program, for example, includes FFTF as a necessary and vital tool to obtain substantial long-range improvements in fuel.

The fo.eign programs differ from the U.S. program in respect to program approach and e..pliasis. For example, the USSR fast reactor program consists of constructing largescale units of different designs so that any deficiencies in plant design, fabrication practices, and technology can be corrected. The French program has emphasized constructina and operatina fast reactor prototypes of increasing size. The Japanese approach is similar to the U.S. approach in that substantial efforts are directed at developing the necessary technology. Moreover, the high population density cf Japan and the frequency of earthquakes, as well as other factors and circumstances, have resulted in licensing criteria and public awareness of nuclear plants similar to that in the United States. Another distinction is that the foreign programs do not include an FFTF-type facility because these countries have not believed this type of facility to be necessary for their programs. ERDA told us that these foreign countries could, if they desired, perform certain experimenis on the FFTF and that one country, West Germany, has approached ERDA on the possibility of doing this.

Although there are some differences in approach and emphasis, all of the programs either contain or plan many of the same elements that are in the long-range U.S. program. The foreign programs either have in operation or under construction or have planned intermediate size LMFBR plants. All these programs are aimed ultimately at commercial-size plants in the thousand megawatt or greater range.

\section{AEC ASSESSMENT OF THE FRENCH}

\section{LMFBR P POGRAM}

According to AEC, the French LMFBR program represents a strong effort with centralized leadership. Less stringent safecy requirements and regulatory procedures, concentrated efforts on one advanced nuclear system, and a strong enaineering tean with requisite authority and capability to expedite the LMFBR efforts have undoubtedly been contributing factors in the rapid advance of the French LMFBR program. 
In October 1974, $A E C$ gave the Office of Management and Budget an assessment of the commercial potential for the French LMEBR program, the attractive features and specific problems associated with the French LMFBR, and the impact if the United states were to depend primarily on French technology for commercial LMFBRs.

According to $A E C$, the safety and licensing requirements for LMFBRs in France are less comprehensive than the U.S. requirements. The rigorous requirements of the United States would tend to reduce the commercial potential of the French LMFBRs here. The French LMFBRs would encounter difficulties getting licensed in the United states in several areas, including

--meeting seismic and tornado design criteria and

--using and enforcing a formal auality assurance program using U.S. derived codes and standards.

AEC saic that these difficulties are not insurmountable but that a large amount of time and some redesign would be needed to meet U.S. requlatory demands. However, the licenseability of reactors of French design has not been explored in the United States.

AEC told the Office of Management and Budget that official capital investment and operating costs for the French LMFBRs are not available. Consequently, AEC was unable to make an accurate projection of their economic attractiveness in the U.S. market.

According to AEC, some of the attractive features of the French LMFBRs are:

'--operating experience from 250 MWe Phenix,

--experience with two steam generator designs for Super Phenix,

--partial (not necessarily complete). component and sub-component testing, and

--apparent low costs.

Some of the problems associated with using French technology are:

--Unknown quality assurance program, but reported to be minimal for the Phenix.

--Unknown availability and cost of fuel. 
--Licensing of foreign reactors or U.S. soil would require substantial analysis and perhaps tests.

--Insuring the availability of spare parts and technology for repair and maintenance.

- Non-availability of programmatic details, oarticularly fuel cycle and component manufacture. The united states could be locked into buying certain French items and services for years to come.

AEC tolc the office of Management and Budget that, if the United States depended primarily on French technology for commerciai LMFBRs, the U.S. balance of payments would be adversely affected and that the united states might not achieve its energy self-sufficiency goal. Also, dependina upon French technology would neqate achieving the objectives of establishing a self-sufficient and growing nuclear power industry and the maintenance of U.S. technclogical leadership in the world by means of a viqorous domestic nuclear power program.

ERDA REVIEW GROUP ASSESSMENT OE POTENTIAL USE OF FOREIGN PROG RAMS

In their January 1975 report on the LMFBR program, an ERDA review group said that foreian LMFBR programs can contribute important data and information to the U.S. program. The group also said that the U.S. program could make use of foreign programs under severa! specific arrangements but that none of these arrangements could be expected to save any large identifiable amount of U.S. effort. These arrangements are:

--Obtaining, under cooperative arrangements, technical information which would otherwise be developed independently. This would include the purchase of foreign data.

--Purchasing components developed in the foreign programs.

- Testing U.S.-developed components and fuel in foreign testing facilities.

The group recommended that

$" * *$ * an active program to obtain and make use of foreign data and experience should be pursued and, if suitable LMFBR components are developed in foreign programs their procurement should be considered." 
The review aroup aiso considered other courses of action, such as (1) relying un obtaining information from a foreign plant instead of building an intermediate-size plant in the United states and (2) dependina totally on foreign sources for LYFBR technology and oowerplants. The aroup concluded

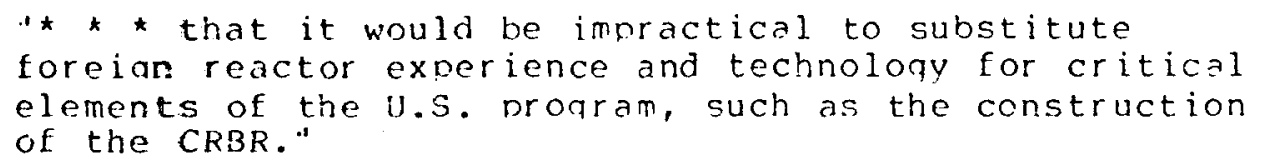

They also said that it is possible in the future to imoort fully developed LNiFBRs from foreign manufacturers, desianed for U.S. conditions and to U.S. standards. However, they concluded

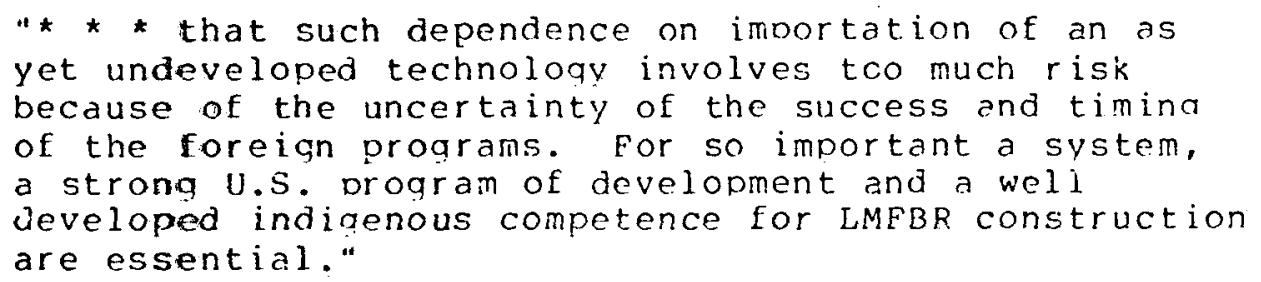

MATTER FOR CONSIDERATION

BY THE CONGRESS

If the Congress wants to know whether areater reliance can be placed on the use of foreian LMFBR technoloav, it should explore with ERDA in greater depth the advantades and disadvantages of using foreign LMFBR technoloqy. 


\section{CHAPTER 6}

\section{SCOPE OF REVIEW}

We made our review at ERDA headquarters in Germantown, Maryland. We held discussions with ERDA staff responsible for managing the LMEBR program and reviewed orogrammatic and fiscal and budgetary documents relating to the program and ERDA documents regarding the status of foreign LMFBR programs.

We visited Argonne National Laboratory, Chicaqo, Illinois, to obta in data on LMFBR support facilities under their cognizance. ERDA obtained similar information for us from other national laboratories and contractors.

To develop information on total Federal energy research and development, we held discussions with and obtained documents from office of Manaqement and Budget and National science Foundation officials. 


\begin{tabular}{|c|c|c|c|c|c|c|c|c|c|c|}
\hline 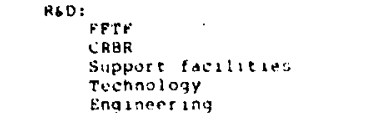 & $\begin{array}{l}95 \\
42 \\
43 \\
42 \\
40 \\
40\end{array}$ & $\begin{array}{c}513 \\
310 \\
31 \\
36 \\
: 5\end{array}$ & $\begin{array}{l}113 \\
114 \\
114 \\
15 \\
15\end{array}$ & 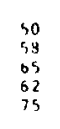 & $\begin{array}{l}40 \\
46 \\
68 \\
65 \\
102\end{array}$ & $\begin{array}{c}40 \\
40 \\
69 \\
68 \\
134\end{array}$ & $\begin{array}{l}258 \\
253 \\
310 \\
319 \\
429\end{array}$ & $\begin{array}{c}565 \\
\text { s35 } \\
3176 \\
738 \\
1770\end{array}$ & $\begin{aligned} 265 \\
201 \\
201 \\
121 \\
84\end{aligned}$ & $\begin{array}{r}830 \\
351 \\
977 \\
959 \\
1254\end{array}$ \\
\hline 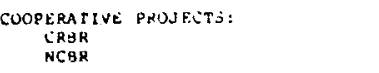 & 14 & 3 & 20 & 164; & $\begin{array}{r}178 \\
20\end{array}$ & 177 & $\begin{array}{l}5 y 3 \\
95\end{array}$ & $\begin{array}{l}838 \\
300\end{array}$ & : & $\begin{array}{l}838 \\
100\end{array}$ \\
\hline CAPITAL EUUS PMENT & .19 & is & s & 25 & 26 & 28 & 121 & $: 91$ & si & 344 \\
\hline $\begin{array}{l}\text { CONSTRUCTION PROJECTS: } \\
\text { Feff }\end{array}$ & 132 & $: 10$ & & 100 & - & - & 312 & 312 & - & 312 \\
\hline $\begin{array}{l}\text { Plant component teat facti- } \\
\text { ity }\end{array}$ & - & - & - & 13 & 53 & 65 & 131 & 200 & - & 200 \\
\hline 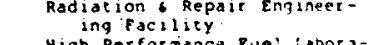 & - & - & - & - & 4 & 13 & 17 & 36 & - & 35 \\
\hline 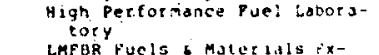 & - & - & - & 9 & 18 & 18 & 45 & 54 & . & 54 \\
\hline 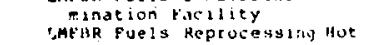 & & & - & - & 5 & 18 & 23 & so & $\cdot$ & 50 \\
\hline 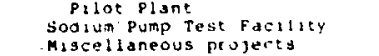 & is & 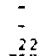 & 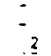 & ig & 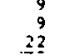 & $\begin{array}{r}37 \\
18 \\
.19\end{array}$ & $\begin{array}{r}46 \\
27 \\
99\end{array}$ & $\begin{array}{l}300 \\
100 \\
203\end{array}$ & $\vdots$ & $\begin{array}{l}300 \\
200 \\
202\end{array}$ \\
\hline TOral LMFUK & 430 & $9 ! 1 ?$ & $9 \underline{9}$ & 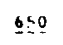 & $66 \underline{6}$ & 8118 & 30201을 & 6323 & 234 & 2047 \\
\hline 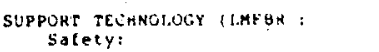 & & & & & & & & & & \\
\hline 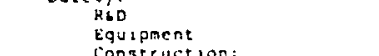 & 奧 & $4 !$ & 3 & $\begin{array}{c}63 \\
5\end{array}$ & ${ }_{6}^{69}$ & 7 & $\begin{array}{l}229 \\
25\end{array}$ & $\begin{array}{c}778 \\
62\end{array}$ & $\begin{array}{l}245 \\
18\end{array}$ & $\begin{array}{c}1023 \\
80\end{array}$ \\
\hline 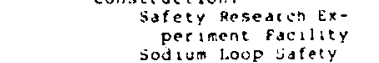 & - & - & - & ${ }^{13}$ & 29 & 61 & 103 & 230 & - & 230 \\
\hline 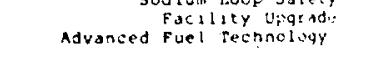 & it & il & $\therefore$ & ?ִ & 23 & 30 & 103 & $.3 ? 8$ & 109 & 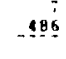 \\
\hline 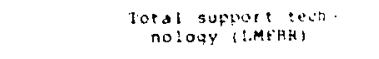 & $.5 !$ & ? & 16 & $10 !$ & 1313 & $12 ?$ & $\underline{215}$ & 1035 & m!n & $\lfloor\underline{8} 26$ \\
\hline 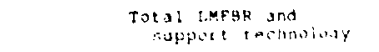 & 491 & $1 \div 4$ & 114 & $25 !$ & 298 & $\underline{995}$ & 3613 & $\underline{1711}$ & 1095 & 8873 \\
\hline
\end{tabular}


LMFBR PROGRAM MAL'OR

PARTICIPANTS BY PROGRAM AREA

\section{REACTOR PHYSICS}

Aerojec ivelear Corporation Argonne National Laboratory Brookhaven National Laboratory General Electric Company Hanford Eng ineering Develodment Laboratory Los Alamos Scientific Laboratory Hol if ield National Laboratory Westingtouse Electric Corporation

\section{FUELS AND MATERIALS}

P.rgonne National Laboratory Atomics International Battelle Memorial Institute Combustion Engineering General Electric Company Hanford Eng ineer ing Development Laboratory Los Alamos Scientific Laboratory Naval Research Laboratories Holifield National Laboratory Westinghouse Electric Corporation

\section{FUEL RECYCLE}

Aeroject Nuclear Corporation E. I, du Pont de Nemours \& Co. Hanford Eng ineering Development Laboratory Los Alamos Scientific Laboratory Oak Ridge Gaseous Diffusion Plant Holifield National Laboratory Sandia Corporation

\section{SAFETY}

Aeroject Nuclear Corporation

Argonne National Laboratory

Atomics International

General Electric Company

Hanford Engineer ing Development Laboratory Los Alamos Scientif ic Laboratory

Holifield National Laboratory Southwest. Research Institute Westinghouse Electric Corporation 


\section{COMPONENT DEVELOPMENT}

Aerojet General Corporation

A $\in$ rojet Nuclear Corporation

Argonne National Laboratory

Atomics Internationa?

General Electric Company

Hanford Eng ineering Development Laboratory Holifield National Laboratory

Westinghouse Electric Corporation

\section{PLANT EXPERIENCE}

Argonne National Laboratory

Atomics International

Bechtel corporation

Burns and Poe, Inc.

General Electric Company

Hanford Engineer ing Development Laboratory Westinghouse Electric Corporation 


\section{LMFBR PROGRAM FACILITY RELATIONSHIPS}

REACTOR PHYSICS PAOGRAM
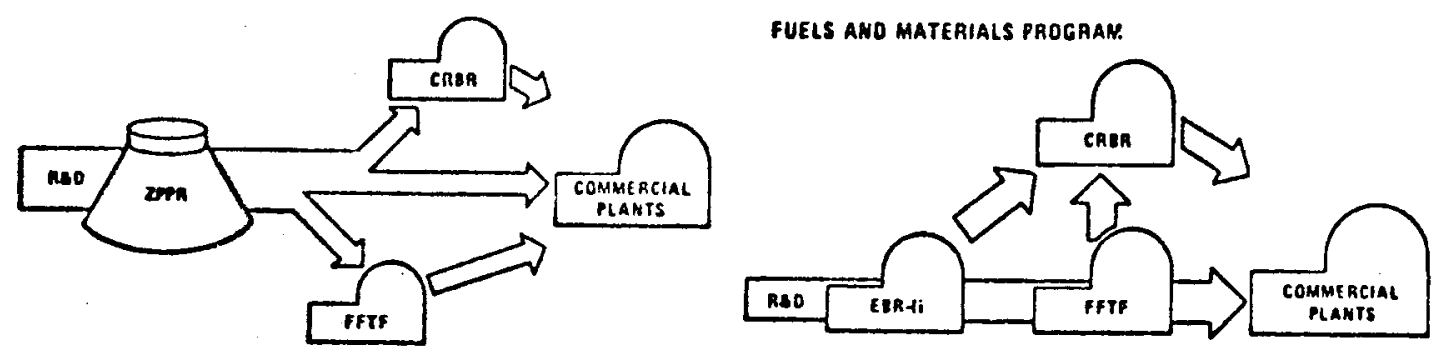

FUEC RECYCLE RROGRAM

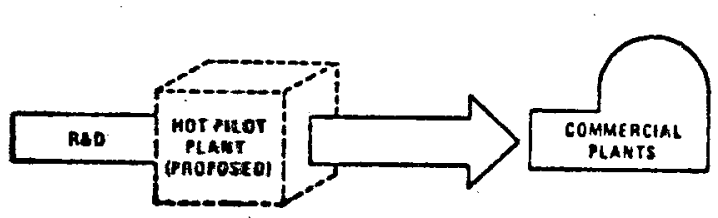

\section{SAFETY PAOGAAM}
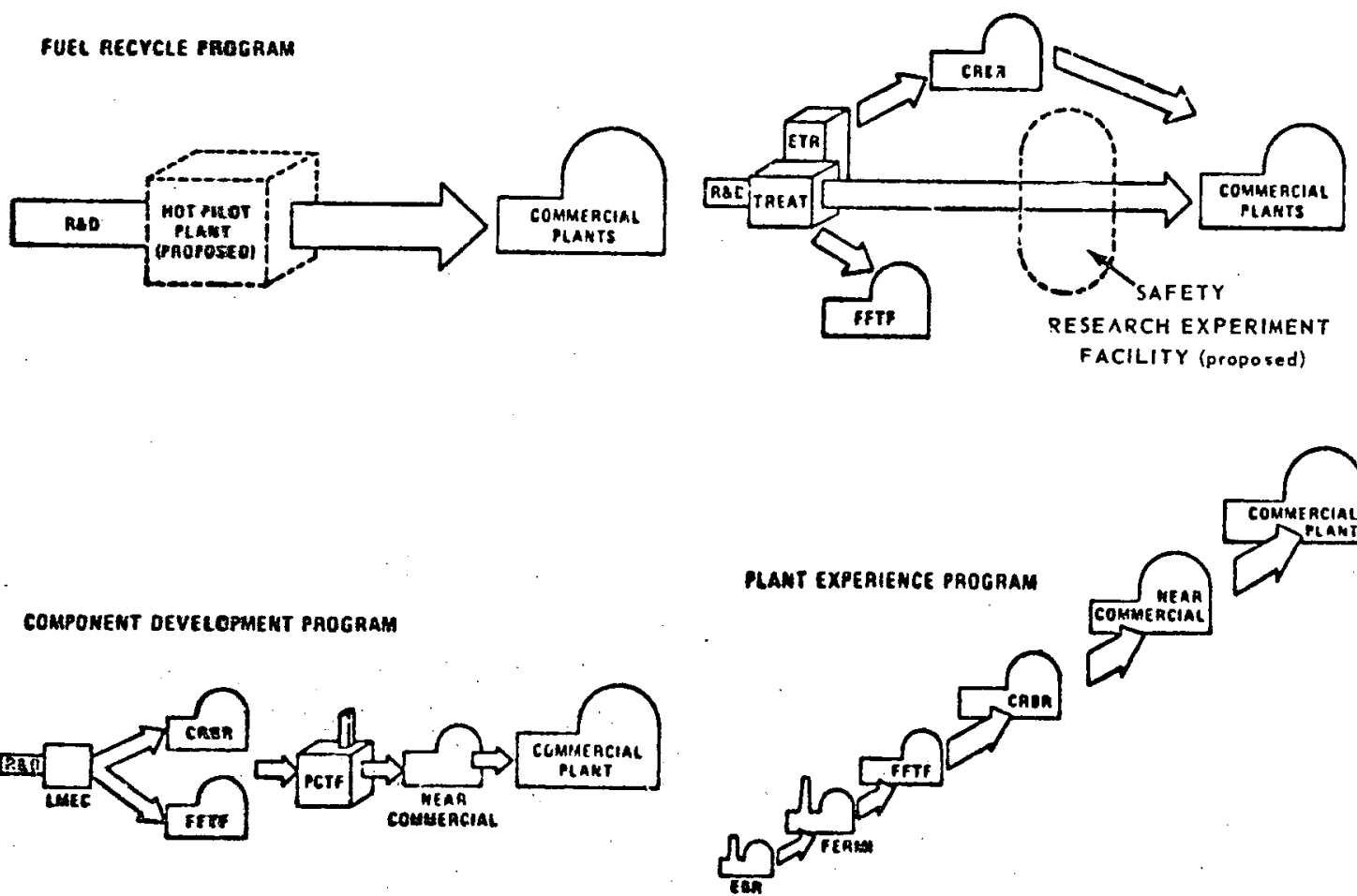
LMFBR PROGRAM MAJOR

FACI ITIES BY PROGRAM AREA

\section{REACTOR PHYSICS}

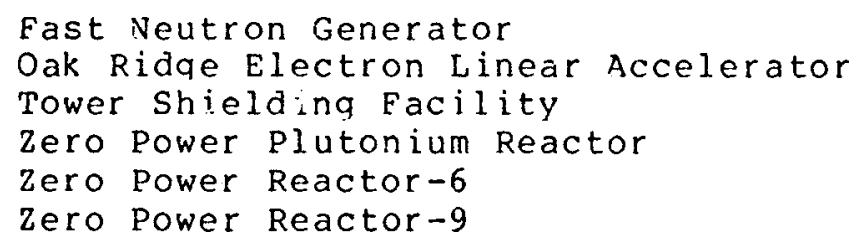

\section{FUELS AND MATERIALS}

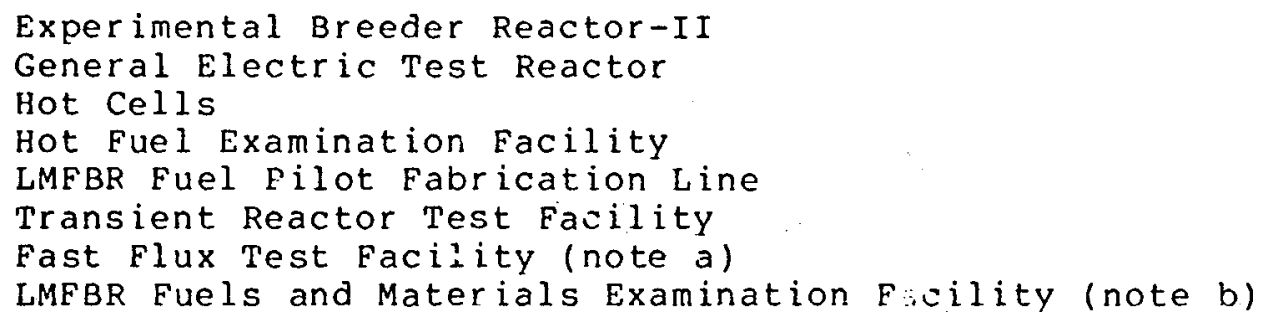

FUEL RECYCLE

High Performance Fuel Laboratory (note b)

LMFBR Fuels Reprocessing Hot Pilot Plant (note b)

\section{SAFETY}

Fuel Failure Mockup

Hot Fuel Examination Facility

Power Burst Facility

Transient Reactor Test Facility

Sodium Loop Safety Facility (note a)

Safety Research Experiment Facility (note b)

\section{COMPONENT DEVELOPMENT}

High Temperature Sodium Facility

Small Component Evaluation Loop

Small Component Test Loop

Sodium Components Test Installation (note $c$ )

Alkali Metal Cleaning Facility (note a)

Component Handling and cleaning Facility (note a)

Large Leak Test Rig (note a)

Sodium Pump Test Facility (note a)

Plant Component Test Facility (note b)

Radiation and Repair Engineering Facility (note b)

Transient Test Facility (note b) 


\section{PLANT EXPERIENCE}

Experimental Breeder Reactor-I (note d) Experimental Breeder Reactor-II

Enrico Fermi Atomir Power Plant (note d)

Southwest Experimental Fast Oxide Reactor (note d) Fast Flux Test Facility (note a)

Clinch River Breeder Reactor (note $b$ )

Near Commercial Breeder Reactor (note b)

a Under construction

b planned

CBeing modified

$a_{\text {Decommissioned }}$ 
SCHEDULE OF ERDA-FUNDED

FACILITIES USED IN SUPPORT OF

THE LMFER PROGAAM

LOCATION ABBREVIATIONS

ANL

Argonne National Laboratory, Chicaqo, Ill inois

HEDL

Hanford Engineering Davelopment Laboratory,

Richland, Washington

HNL

Hol ifield National Latcratory, Oak Ridge,

Tennessee

INEL Idaho National Engineering Laboratory, Idaho

Falls, Idaho

LMEC Liguid Metal Engineering Center, Santa Susana, California 


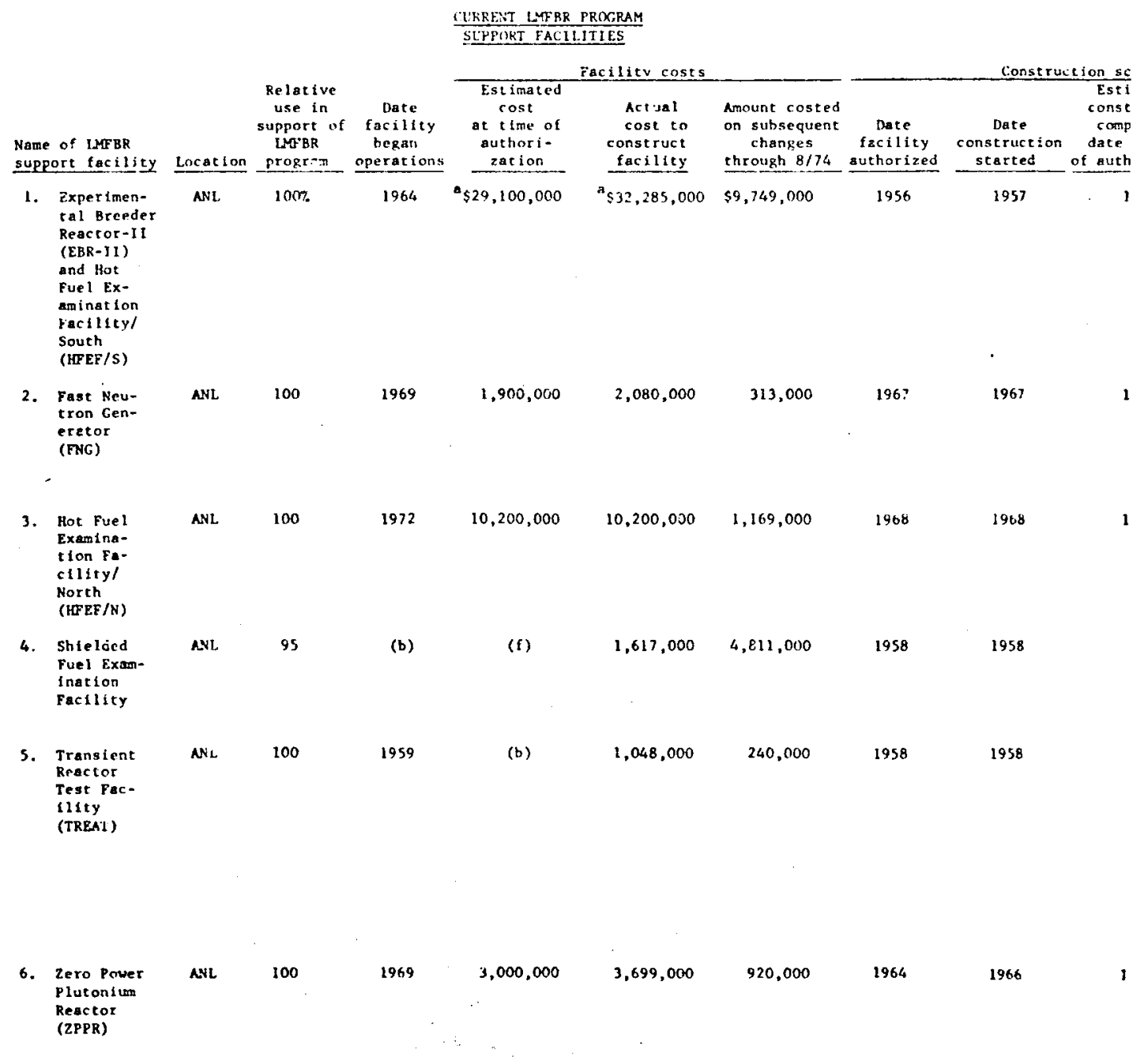




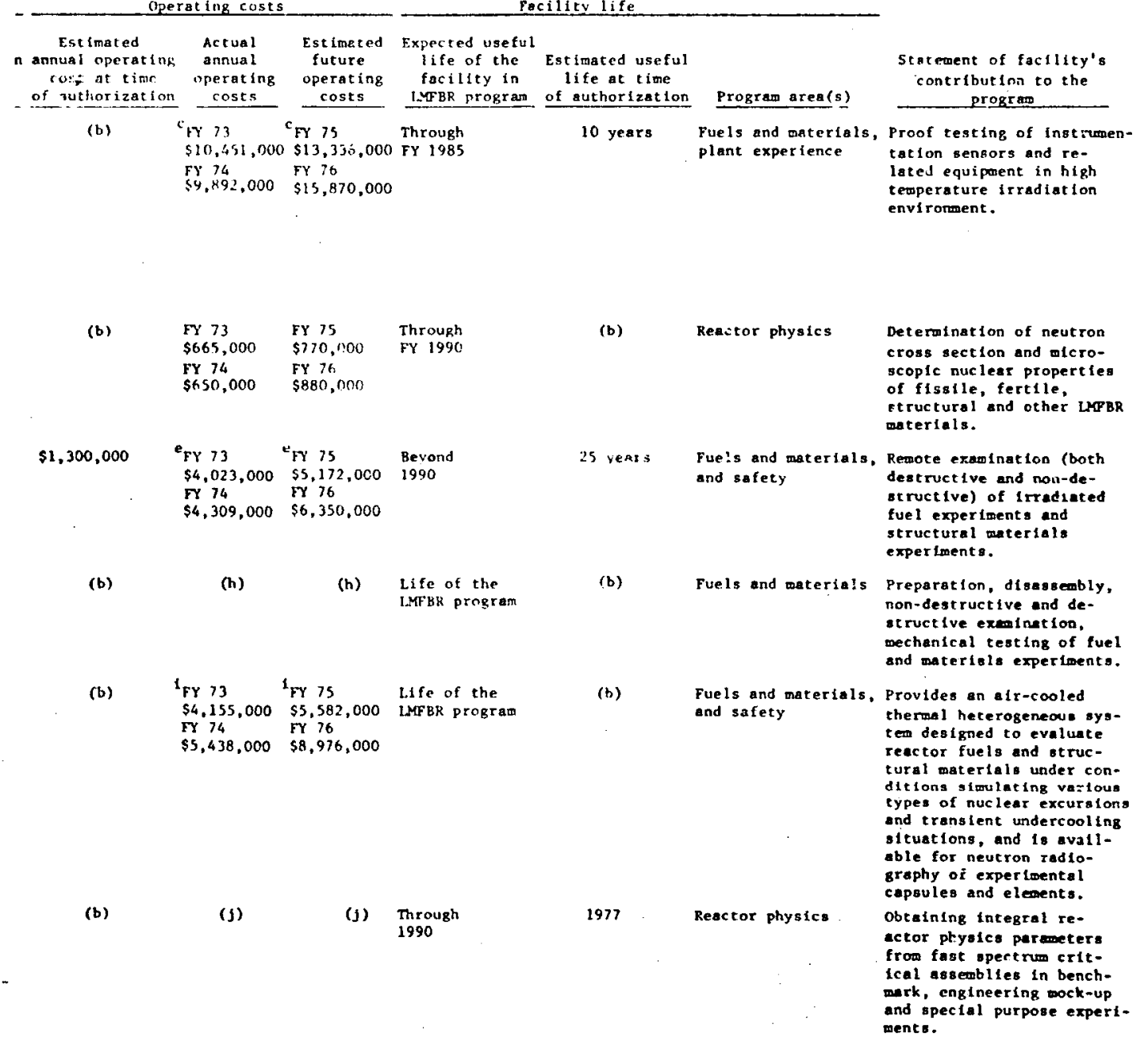




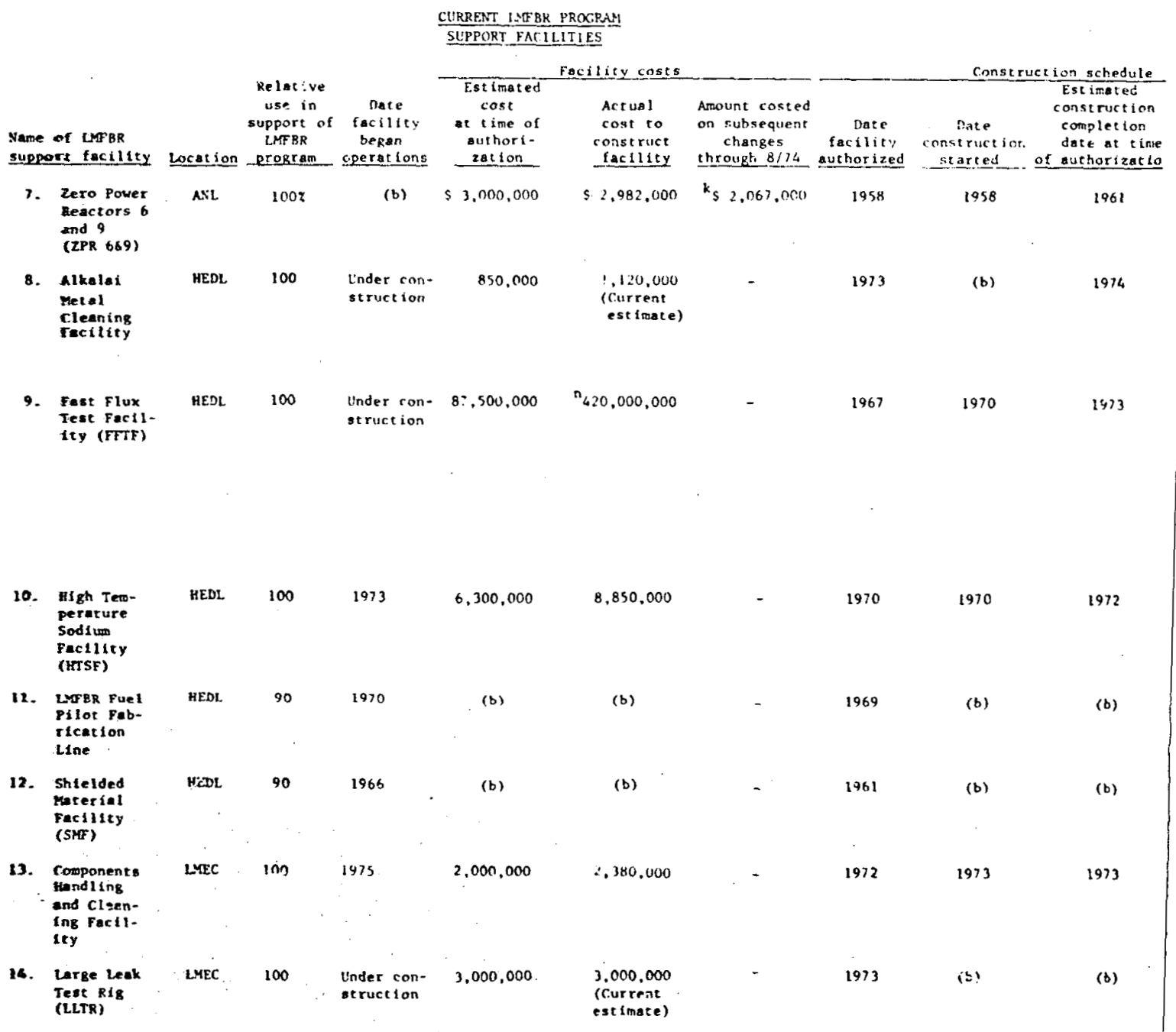




\begin{tabular}{|c|c|c|c|c|c|c|}
\hline \multicolumn{3}{|c|}{ Geveat ing costs } & \multicolumn{3}{|c|}{ Fecilley life } & \multirow[b]{2}{*}{$\begin{array}{c}\text { Statement of facility's } \\
\text { contribution to the } \\
\text { grogram }\end{array}$} \\
\hline $\begin{array}{l}\text { mated } \\
\text { operating } \\
\text { at time } \\
\text { lorization }\end{array}$ & $\begin{array}{c}\text { Actual } \\
\text { annual } \\
\text { operat Ing } \\
\text { costs } \\
\end{array}$ & $\begin{array}{c}\text { Estimated } \\
\text { future } \\
\text { operating } \\
\text { costs } \\
\end{array}$ & $\begin{array}{l}\text { Expected usefut } \\
\text { life of the } \\
\text { facility in } \\
\text { MPER program }\end{array}$ & $\begin{array}{l}\text { Est lmated useful } \\
\text { IIfe at ime } \\
\text { of autharization }\end{array}$ & Erogram arearsi & \\
\hline (b) & (j) & (j) & $\begin{array}{l}\text { Through } \\
\text { Fr } 1980\end{array}$ & (b) & Reactor physies & Same os ZPPR \\
\hline (b) & (1) & (b) & 20 vears & (m) & $\begin{array}{l}\text { romponent develop- } \\
\text { ment }\end{array}$ & 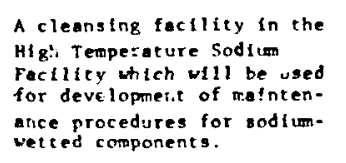 \\
\hline (b) & (1) & $\begin{array}{l}\$ 2,500,000 \\
\text { per year }\end{array}$ & $\begin{array}{l}1995 \text { and } \\
\text { beyond. }\end{array}$ & (b) & $\begin{array}{l}\text { Fuels and mater- } \\
\text { iat. and plant } \\
\text { experience }\end{array}$ & $\begin{array}{l}\text { Provides highegt performance } \\
\text { and largest fuel testing } \\
\text { capacility in the vorld. } \\
\text { providing multipliclty of } \\
\text { test positions. In design, } \\
\text { construction, and operation } \\
\text { serves as vehicle for de- } \\
\text { veloping larger component } \\
\text { engineerting technology. }\end{array}$ \\
\hline 350,000 & (b) & (b) & $\begin{array}{l}\text { about } 20 \\
\text { years }\end{array}$ & (m) & $\begin{array}{l}\text { Component develop- } \\
\text { ment }\end{array}$ & $\begin{array}{l}\text { Testing reactor core com- } \\
\text { ponents in sodium ond } \\
\text { devel npment of operat fonel } \\
\text { and maintenance procedures. } \\
\text { for soditm-wetied components }\end{array}$ \\
\hline (b) & (b) & (b) & 10 years & (b) & $\begin{array}{l}\text { Fuels and mater- } \\
\text { isls }\end{array}$ & $\begin{array}{l}\text { Develop, demonstrate. and } \\
\text { opt imize process. techniques } \\
\text { end equiprent for fabricating } \\
\text { fuels. }\end{array}$ \\
\hline (b) & (b) & (b) & 20 years & (b) & $\begin{array}{l}\text { Fuels and mater- } \\
\text { fals }\end{array}$ & $\begin{array}{l}\text { Nondest-uctive examination } \\
\text { and testing irradiated re- } \\
\text { actor fuels and seructural } \\
\text { materials. }\end{array}$ \\
\hline (b) & (1) & (b) & 10 years & 10 years & $\begin{array}{l}\text { Component develop- } \\
\text { ment }\end{array}$ & $\begin{array}{l}\text { Provides capability for } \\
\text { haridiling large sodium-wetted } \\
\text { components, removing sodium. } \\
\text { and inspecting and repa!ring. }\end{array}$ \\
\hline (b) & (1) & (b) & 3 years & 3 years & $\begin{array}{l}\text { Component develop. } \\
\text { ment }\end{array}$ & $\begin{array}{l}\text { Provides dati on lerge } \\
\text { water sndium leaks ade- } \\
\text { quecy of relief systems } \\
\text { and copability of systems } \\
\text { to uithstand consequences. }\end{array}$ \\
\hline
\end{tabular}




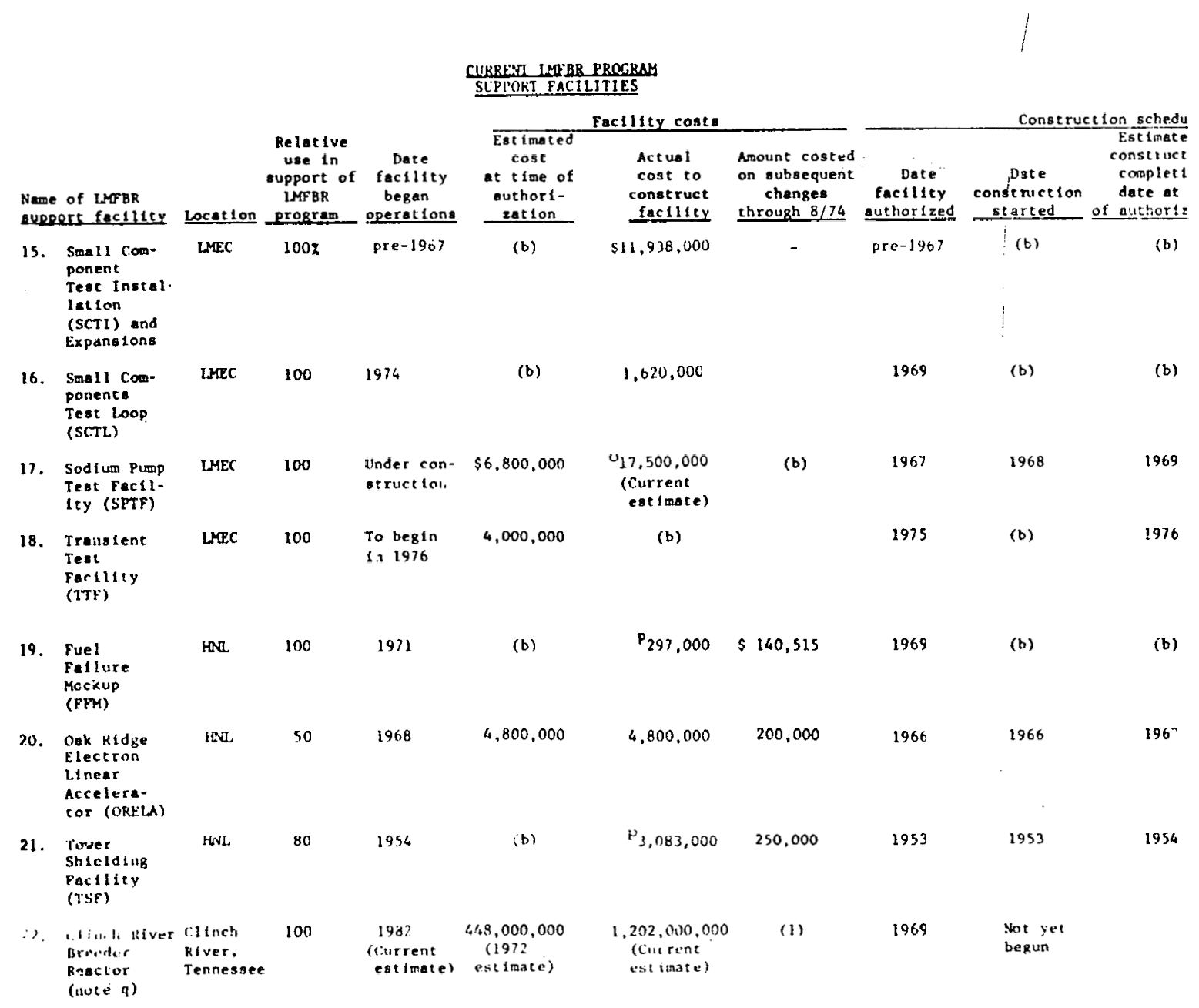


Operat ing costs

\begin{tabular}{|c|c|c|}
\hline $\begin{array}{l}\text { Est fmated } \\
\text { inual operating } \\
\text { cost at time } \\
\text { guthortagtion }\end{array}$ & $\begin{array}{l}\text { Actual } \\
\text { annial } \\
\text { operat Ing } \\
\text { costg } \\
\end{array}$ & $\begin{array}{l}\text { Estimated } \\
\text { future } \\
\text { operating } \\
\text { costs } \\
\end{array}$ \\
\hline
\end{tabular}

(b)

(b)

(b)
Expected useful

life of the Eatimated useful life of the Eatimated useful
faclilty in life at tre WFBR progrem of authorization Progranarea(a)

10-year and test article

10-year and 2- to 3-year
teat article

Component development

\section{Staterent of fectlity'. contribut on to the program}

Teoting oodium-heeted otem generators, odf im - to-nod i um heat exchangera, oodiua-toair heat exchangers, and verfoue in-line cooponente and instrumentation.

(b)

(1)

(b) 20 years

10 years

Component development

Testing of componente and inet rumentetion in codiua. Including thermel testing.

(b)

(1)

(b) 10 yeare

10 years

Component development

Hydraulic and thermal treat ment tear $10 \mathrm{~g}$ of fuel are sodium mechenical pumpo.

$\$ 500,000$

(1) $\$ 500,000 \quad 15$ years

15 years

Component development

Investigates effect of thermal cranslente on $\mathrm{per}$ formance of valves, tees, and other fitting:.

(b)

(b)

(b) At least 2 years

Safety

Invest1gates thermal hydraulics of fuel aubssembilea a related to fallure and fallure propagation.

(b)

(b)

(b) At least

5 years

keactor phyolco

Measurement of neutron crose sectlons and LMPBR materials.

Reactor physics

Provides integral reactor chielding dealgn date end verification of ohfeloing deolgn poreweters.

Plant expertence

Demonstration of LAPBR eafety. rellebility, opera-

sility, avallabllity.

ineintainablity. flexiblity,

inapectablitiy, envil romental inceptabllity, and prospecte for econony. 


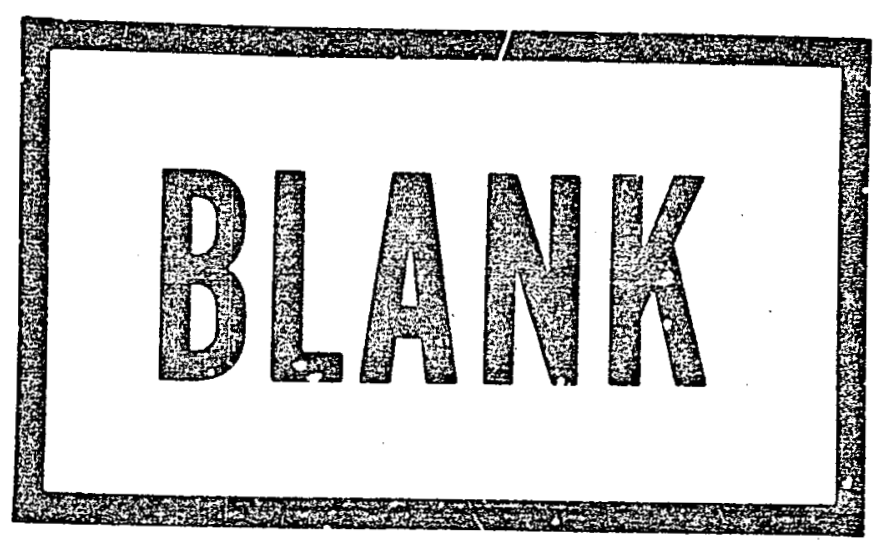


FOOTNOTES

ancludes fuel cycle facility - HFEF/S.

bivot readily available.

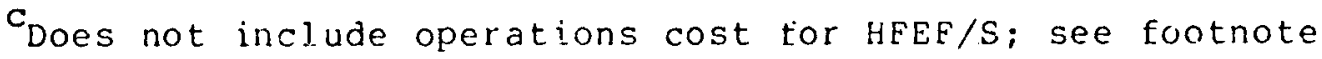
e.

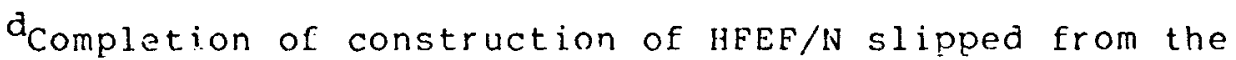
first quarter $0 \equiv 1971$ to the last quarcer of 1971 because construction funds were released 1 year after the date expected.

$\mathrm{e}_{\mathrm{HFEF} / \mathrm{N}}$ operations costs are not specifically identifiable but $r$ ather are combined with $\mathrm{HFEF} / \mathrm{S}$ costs. The costs represented here are the combined costs for these two iaciities.

Especific amount was not readily available as it was included as part of a $\$ 10 \mathrm{milli}$ ion Fuel Technology Center.

gNot available.

$\mathrm{h}_{\text {Cost }}$ or operations for this facility are not identifiable as they are included in a multiactivity type of operation

$i_{\text {TREAT }}$ Operating

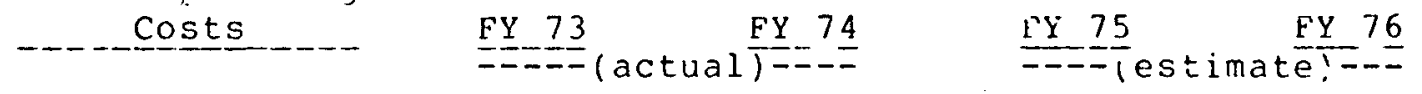

Cost of operations $\$ 952,000 \quad \$ 1,739,000 \quad \$ 2,082,000 \quad \$ 3,760,000$

Cost of experiments using the facility

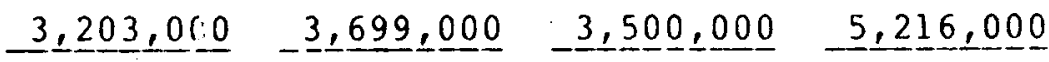
Total $\$ 4,155,000 \quad \$ 5,438,000 \quad \$ 5,582,000 \quad \$ 8,976,000$

$j_{Z P P R}, Z P R-6,2 P R-9$, and other costs arf intermingled within the Fast Critical Facilities costs and, therefore, are not individually icentifiable by $A E C$.

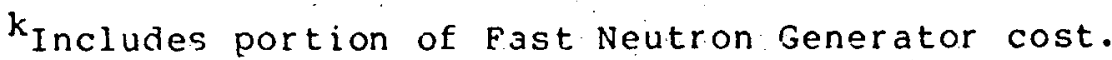

$1_{\text {Not }}$ applicable.

MCannot be determined at this time. 
FOOTNOTES (cont'd.)

$n$ The FFTF contractor is presently forecastina that an additional $\$ 92$ million will be needed for construction of FFTF and that construction will be completed in August 1978 .

- AEC is presently planning modification to the SPTF so it can accept $\mathrm{Cl}$ inch River Breeder Reactor pumps for testing. These modifications are planned to beg in in fiscal year 1978 and are estimated to cost $\$ 40$ million.

PFigure represents gross book value of facility as of June 30,1974 .

The $\mathrm{Clinch}$ River Breeder Reactor is a cooperative government/industry effort. The total project cost is presently estimated at $\$ 1.736$ billion versus the initial estimate of $\$ 699 \mathrm{milli}$ ion. These costs include development and operating costs and escalation, as follows:

\section{Initial Estimate current Estimate (1972) \\ (1974)

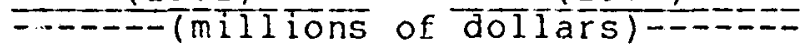

Plant investment Development cost Operating cost ( 5 year)

Total project cost

Escalation

Total project cost

(less escalation)

$\begin{array}{r}\$ 448 \\ 194 \\ -57 \\ \hline\end{array}$

$\$ 699$

159

$\$ 540$
$\$ 1202$

434

$-100$

$\$ 1736$

498

$\$ 1238$

of the total project cost of $\$ 1.736$ billion, AEC is expected to contribute $\$ 1.468$ billion and industry $\$ 268$ million. 
PLANNED LMFBR PROCRUM SUPPORT FACILITIES

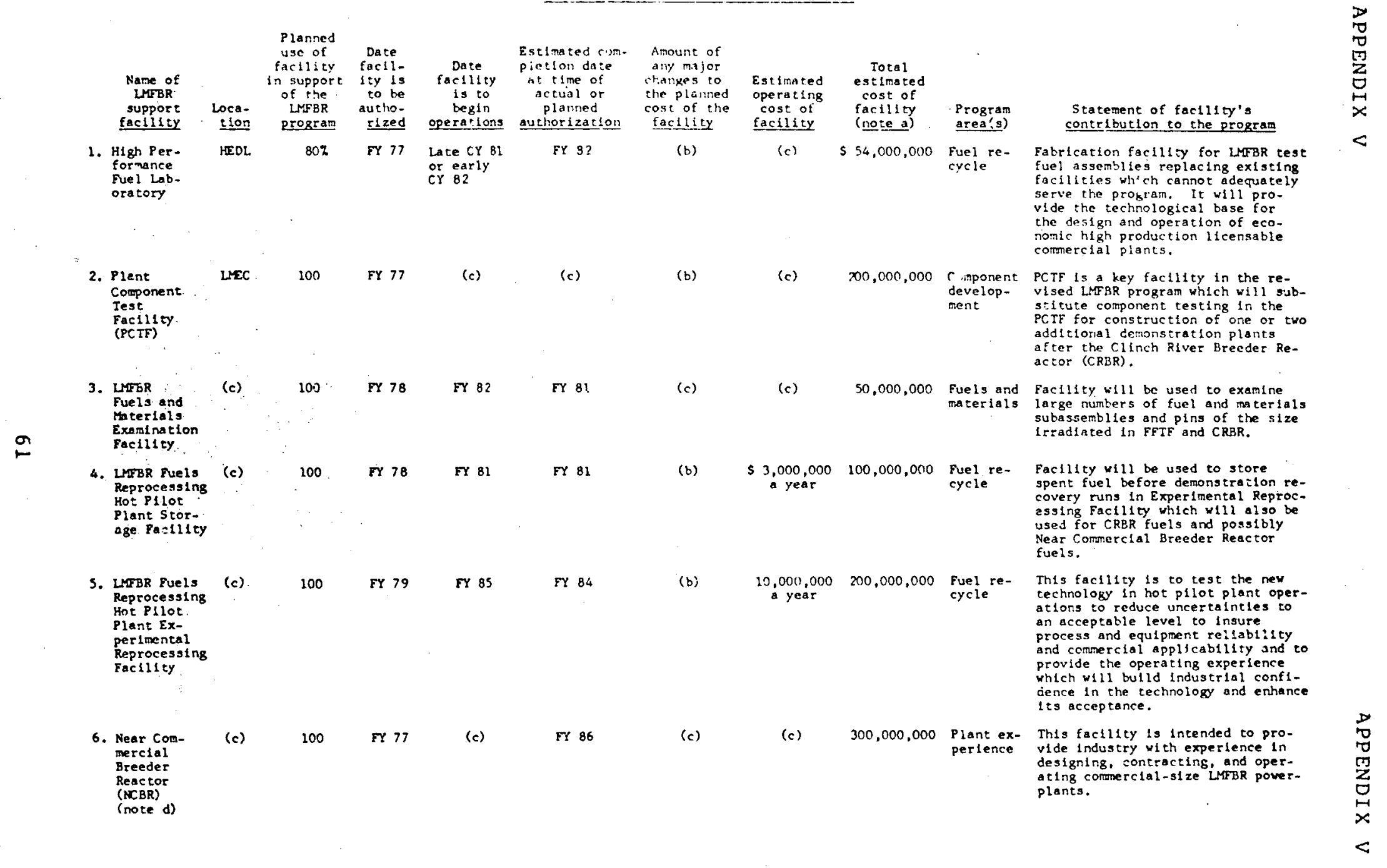


PLANMED LMPBR PROCRAM SUPPORT FACILITIES

\begin{tabular}{|c|c|c|c|c|c|c|c|c|c|c|}
\hline $\begin{array}{l}\text { Mapa of } \\
\text { Lupse } \\
\text { support } \\
\text { facility }\end{array}$ & $\begin{array}{c}\begin{array}{c}\text { Loca- } \\
\text { tlon }\end{array} \\
\text { nan }\end{array}$ & 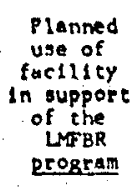 & $\begin{array}{l}\text { Date } \\
\text { gaetlo } \\
\text { aty lo } \\
\text { to be } \\
\text { ateho- } \\
\text { alzed } \\
\end{array}$ & $\begin{array}{c}\text { Date } \\
\text { faclity } \\
15 \text { to } \\
\text { begin } \\
\text { operations }\end{array}$ & $\begin{array}{l}\text { Estimated com- } \\
\text { plettion date } \\
\text { at time of } \\
\text { actual of } \\
\text { planned } \\
\text { suthortzation }\end{array}$ & $\begin{array}{l}\text { Amount of } \\
\text { any major } \\
\text { changes to } \\
\text { the planned } \\
\text { cost of the } \\
\text { factllty }\end{array}$ & $\begin{array}{l}\text { Esstmated } \\
\text { operat Ing } \\
\text { coste of } \\
\text { faclitity }\end{array}$ & $\begin{array}{l}\text { Total } \\
\text { esstimated } \\
\text { costo of } \\
\text { factisty } \\
\text { (note at }\end{array}$ & $\begin{array}{l}\text { Program } \\
\text { ar:a(s) }\end{array}$ & $\begin{array}{l}\text { Statement of faccl11i:'s } \\
\text { contribution to the program }\end{array}$ \\
\hline $\begin{array}{l}\text { 7. Radiation } \\
\text { aivd Repair } \\
\text { Engineace- } \\
\text { Ing Faci- } \\
\text { Iry }\end{array}$ & (s) & 1002 & $\times 78$ & (c) & $\begin{array}{l}\text { About } 5 \text { years } \\
\text { after author:- } \\
\text { zation }\end{array}$ & $\begin{array}{l}\text { Changes being } \\
\text { contemplated } \\
\text { though no } \\
\text { dollat flgure } \\
\text { can be set at } \\
\text { thls time }\end{array}$ & (c) & $\$ 36,000,000$ & $\begin{array}{l}\text { Component } \\
\text { develop- } \\
\text { ment }\end{array}$ & 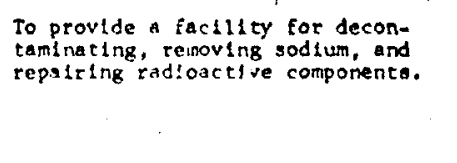 \\
\hline $\begin{array}{l}\text { 8. Safety } \\
\text { Research } \\
\text { Experiment } \\
\text { Facility }\end{array}$ & (c) & 100 & FY 77 & Mid-1980s & (c) & (c) & (c) & $230,000,000$ & Safety & 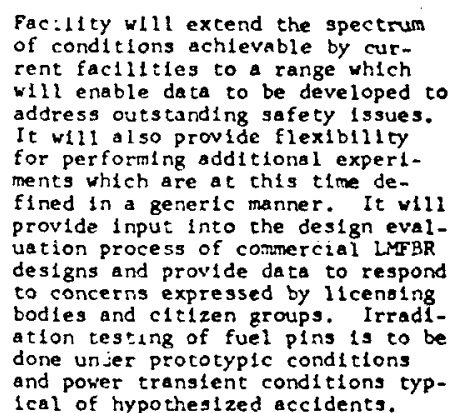 \\
\hline
\end{tabular}

"These are planning estimates. According to ERDA, firmer estimates are being developed for authorization purposes.

bone.

$c_{\text {Not yet determined. }}$

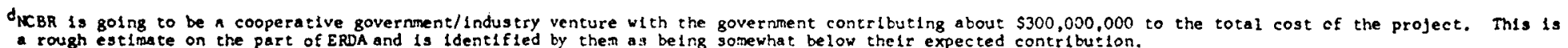


OTHER FACILITIES INVOLVED IN

THE LMFER PROGRAM

In addition to those facilities already presented, many others have been involved in the support of the development of the LMFBR program. These have been involved to varying degrees and are generally less significant in terms of overzll program contribution than those shown on the previous pages. Some of these are shown below

\begin{tabular}{|c|c|c|c|}
\hline Name of facility & Location & status & Program Area \\
\hline $\begin{array}{l}\text { Experimental Breeder } \\
\text { Reactor-I }\end{array}$ & INEL & Retired & $\begin{array}{l}\text { Plant } \\
\text { experience }\end{array}$ \\
\hline $\begin{array}{l}\text { Southwest Experimental } \\
\text { Fast Oxide Reactor }\end{array}$ & $\begin{array}{l}\text { Fayetteville, } \\
\text { Arkansas }\end{array}$ & Retired & $\begin{array}{l}\text { Plant } \\
\text { experience }\end{array}$ \\
\hline $\begin{array}{l}\text { Sodium Loop Safety } \\
\text { Eacility }\end{array}$ & INEL & $\begin{array}{l}\text { Under con- } \\
\text { struction }\end{array}$ & Saiety \\
\hline $\begin{array}{l}\text { Pump Seal Test } \\
\text { Facility }\end{array}$ & LMEC & Operating & $\begin{array}{l}\text { Component dev- } \\
\text { elopment }\end{array}$ \\
\hline Transient Test Loop & HEDL & Operating & $\begin{array}{l}\text { Component dev- } \\
\text { elopment }\end{array}$ \\
\hline $\begin{array}{l}\text { Out-of-Pile Expulsion } \\
\text { and Re-entry Apparatus }\end{array}$ & ANL & Operating & Safety \\
\hline $\begin{array}{l}\text { Argonne Fast Source } \\
\text { Reactor }\end{array}$ & AN L & Operating & $\begin{array}{l}\text { Reactor } \\
\text { physics }\end{array}$ \\
\hline $\begin{array}{l}\text { Core Component Test } \\
\text { Loop }\end{array}$ & ANL & Operating & $\begin{array}{l}\text { Component } \\
\text { elopment }\end{array}$ \\
\hline $\begin{array}{l}\text { Special Environ- } \\
\text { mental Radiometal- } \\
\text { lurgy Facility }\end{array}$ & HEDL & Operating & $\begin{array}{l}\text { Fuels and } \\
\text { materials }\end{array}$ \\
\hline $\begin{array}{l}\text { Large Components } \\
\text { Test Loop }\end{array}$ & LMEC & Retired & $\begin{array}{l}\text { Component dev- } \\
\text { elopment }\end{array}$ \\
\hline $\begin{array}{l}\text { Small Component } \\
\text { Evaluation Loop }\end{array}$ & HEDL & Operating & $\begin{array}{l}\text { Component dev- } \\
\text { elopment }\end{array}$ \\
\hline Hot cells & Various & Operating & $\begin{array}{l}\text { Fuels and } \\
\text { materials }\end{array}$ \\
\hline
\end{tabular}


REACTOR RESEARCH AND DEVELOPMENT DIVISION

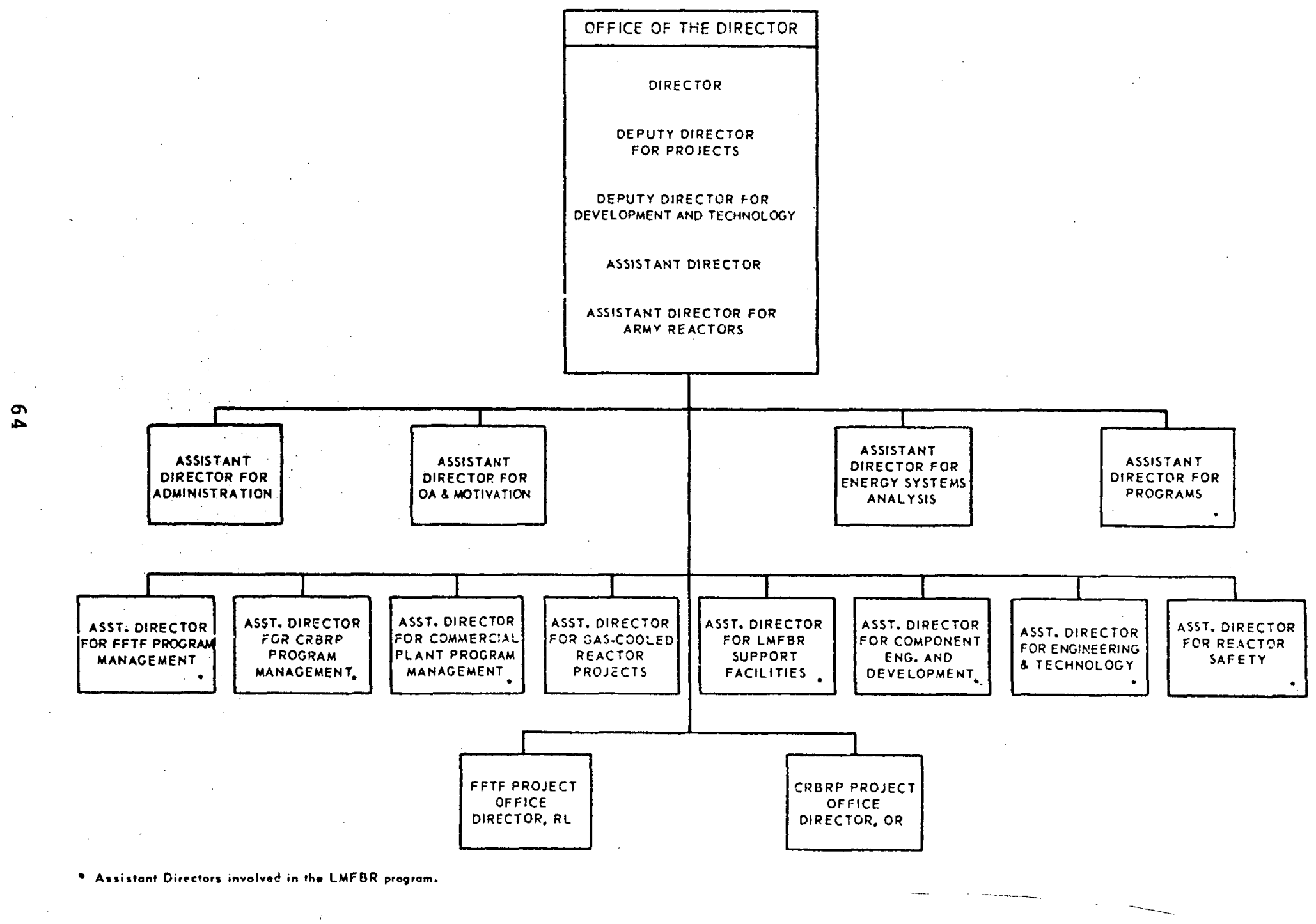




\section{CRBR PROJECT MANAGFMENT ORGANIZATION CHART}

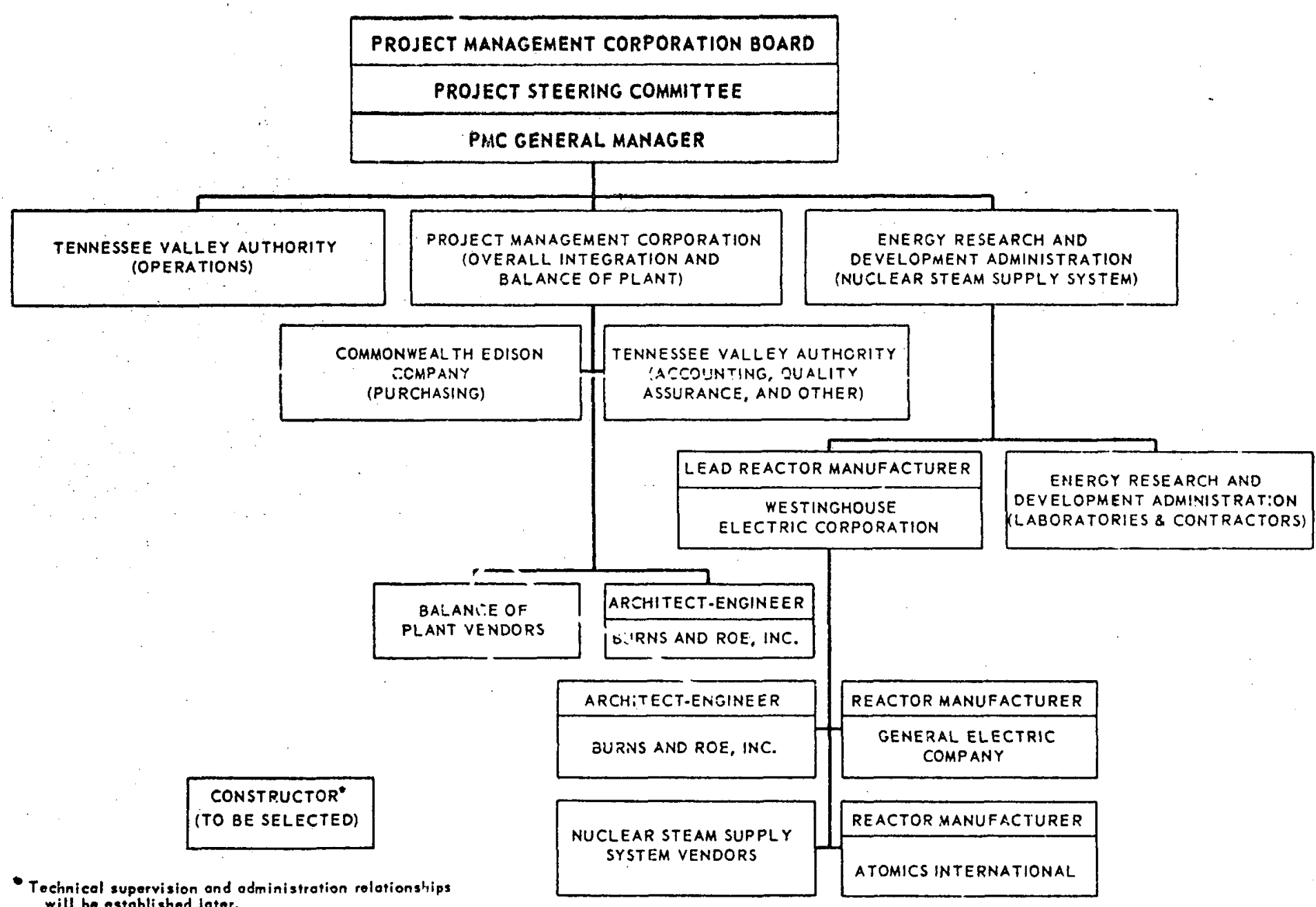


PRINCIPAL OFFICIALS OF AEC AND ERDA RESPONSIBLE FOR ADMINISTER ING THE ACTIVITIES DI SCUSSED IN $\bar{T}$ THI S RE $\overline{\mathrm{H}} \overline{\mathrm{H}} \overline{\mathrm{RT}}$

$\frac{\text { Tenure ct office }}{\text { From }}$

AEC

Chairman:

Dixy Lee Ray

James R. Schlesinger

Glenn T. Seaborg

General Manager:

Robert D. Thorne (acting)

John A. Er lewine

Robert E. Hollingsworth
Feb. 1973 Jan. 1975

Aug. 1971 Feb. 1973

Mar. 1961 Auq. 1971

ERDA

\section{Administrator:}

Robert C. Seamans, Jr.

Jan. 1975 Present

Assistant Administrator for Nuclear Energy:

Robert D. Thorne (acting deputy) Jan. 1975 Present

Jan. 1975 Jan. 1975

Jan. 1974 Dec. 1974

Aug. 1964 Jan. 1974 